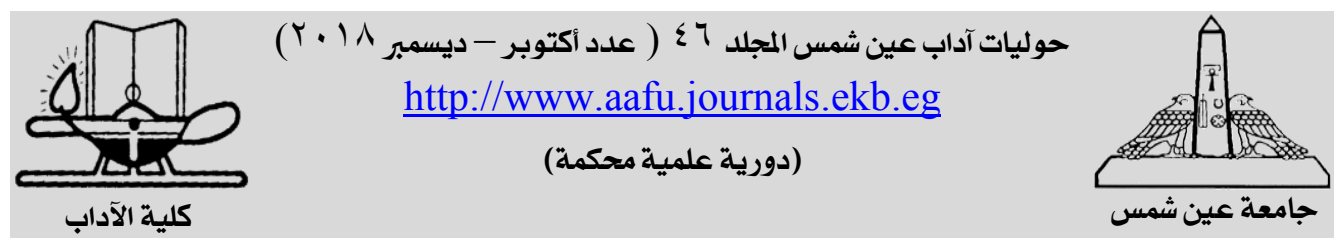

تداخل السرد الفيلمي بين المتخيل والواقع (فيلم خزانة الألم إنموذجا اليفال)

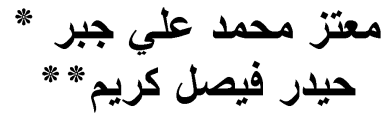

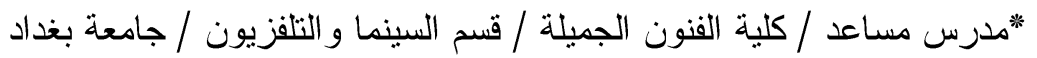

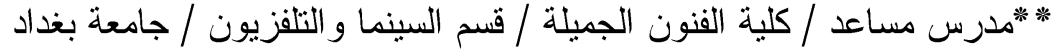

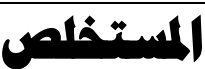

يعتمد الفيلم الروائي على الكثير من التقنيات التي تتراوح ما بين علمية صرفة وفنية صرفة، فتلخل الكثير من التخصصات وتفعل الكثير من العناصر اللغوية من الجل انتاج

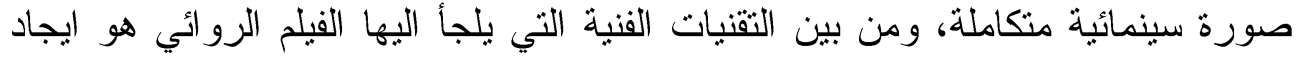

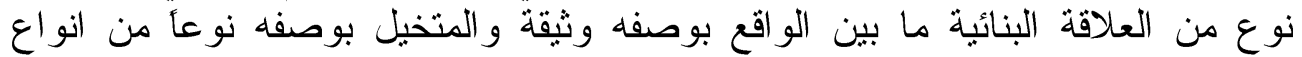

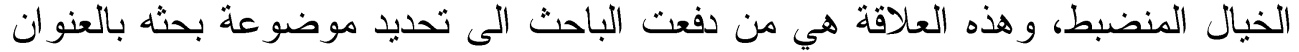

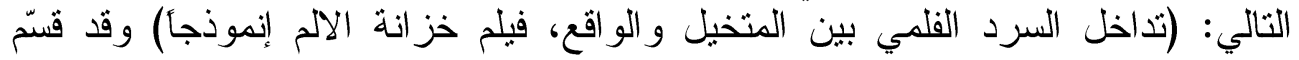

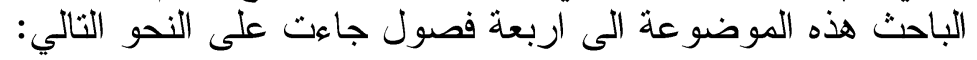

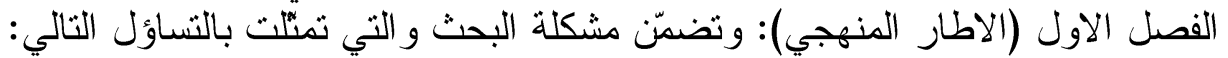

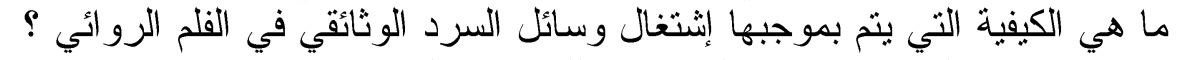

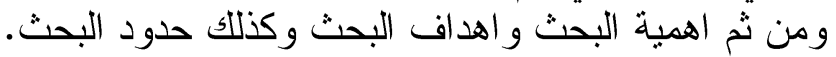

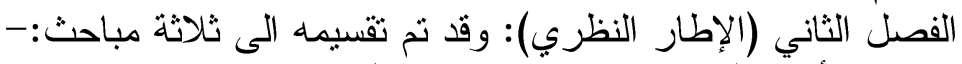

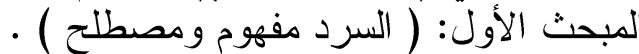

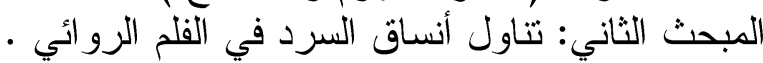

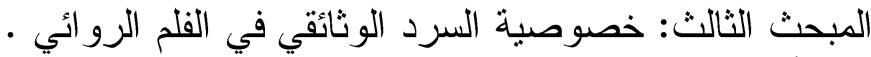

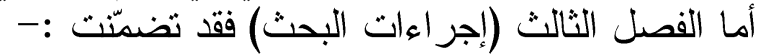

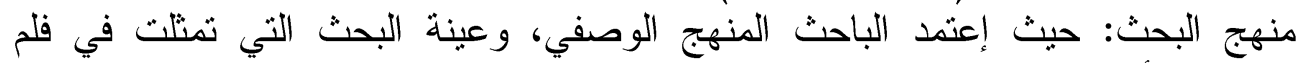

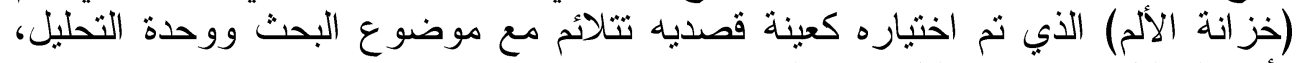

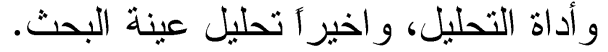
أما الفصل الرابع (النتائج والاستنتاجات) فقد شمل نتائج البحث التي توصّل إليها

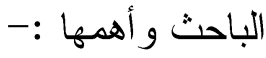
ا. إعتماد حيادية الكامير ا وموضوعينها في سردها للحدث الواقعي داخل بنية الفلم

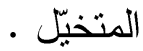
r. إتخاذ الكامير ا موقع المر اقبة للحدث و المتابعة في توثيق سرد الأحداث داخل الفلم

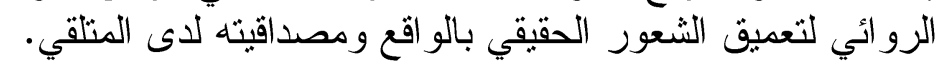

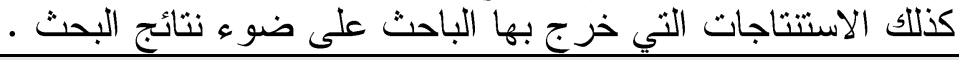

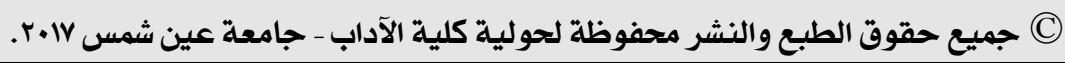




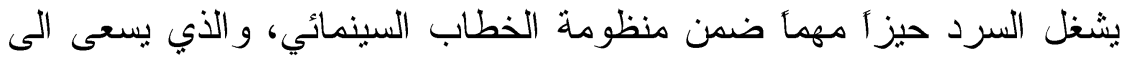

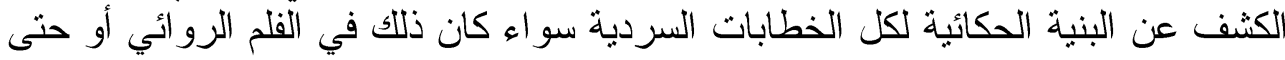

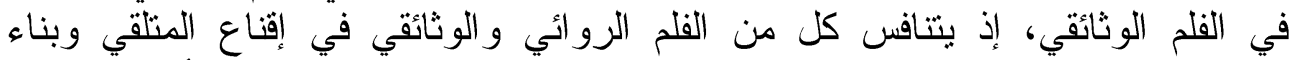
الموضوع، وقد ثتم المقاربة بين الفلم الروائي و الفلم الوثائقي بإستخدام أشنكال جديدة

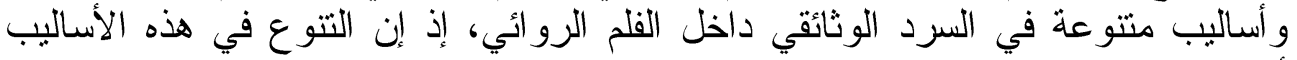

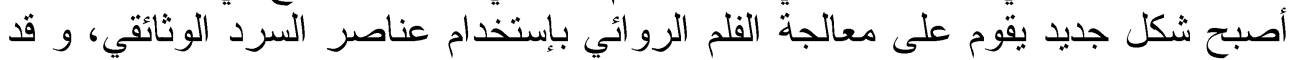

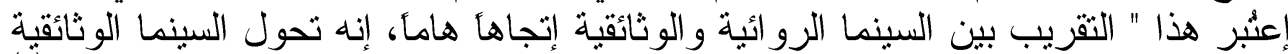

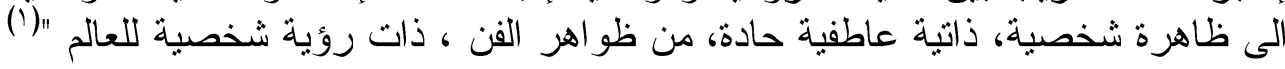

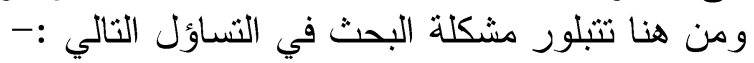

$$
\text { أهميةٌ البحث: الكيفة التي يتم بموجبها إثتغال وسائل ألسرد الوثائقي في الفلم الروائي ؟ }
$$

تحتل الأفلام الروائية ذات الملامح الوثائقية اليوم مكانة كبيرةً بين المشاهدين كما إن الن المان

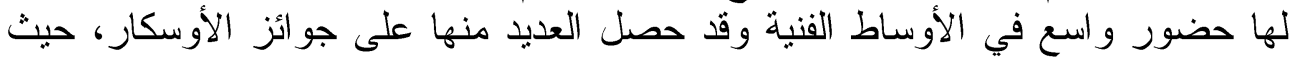

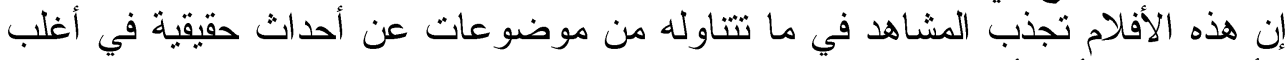

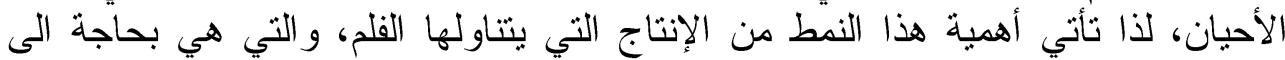

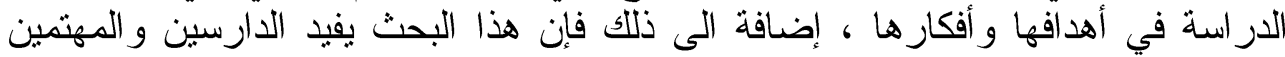

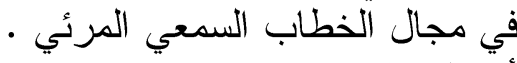

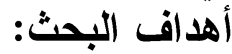

يهدف البحث الى الكثف عن الكيفية التي يتم من خلالها إشتغال وسائل سرد الفيلم

$$
\text { الوثائقي في الفلم الروائي. }
$$

يتحدد البحث بالعينة المختارة قصديأ وهي فلم (خزانة الألم) لأسباب سيتم تحديدها في

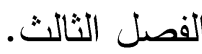

\section{تحديا المصطلحات:}

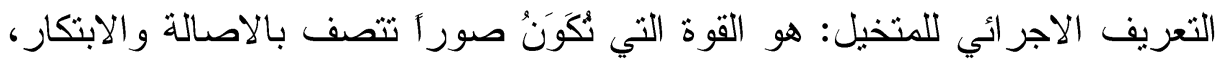

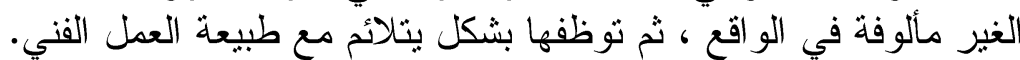

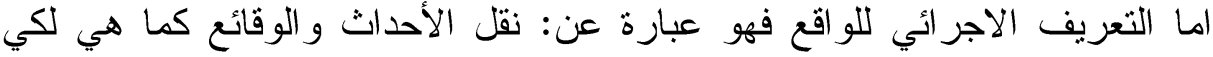

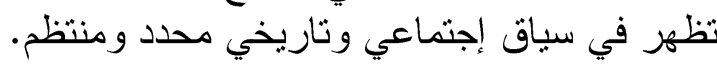
الفصل ألثاني (الاطار ألنظري)

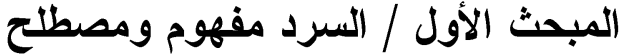

يمثل السرد احد العناصر البنائية التي تعمل في كل النتاجات الفنبة الابداعية الانسانية بسبب الحاجة الملحة الى تقنياته وما يمكن ان بحمله كرسالة ووسيط متكامل ما بين

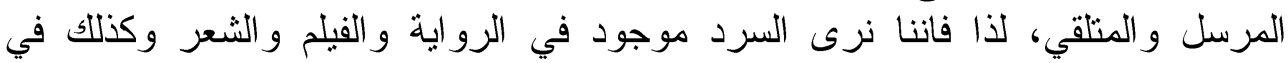

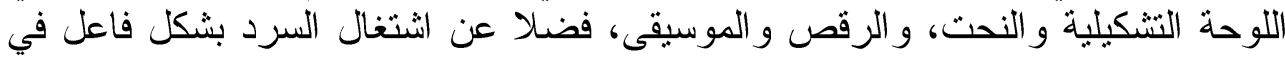

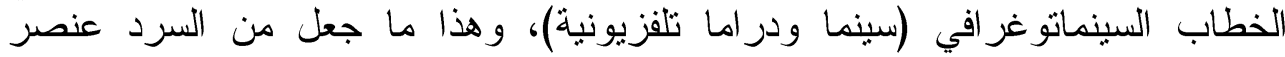
متو افر في العديد من البحوث، اذ تصدى العديد من المنظرين و النقاد لمفهوم السرد 
وتحديده الاصطلاحي، فضلا عن تقنباته الاشتغالية التي تنوعت بتتوع الوسيط الفني

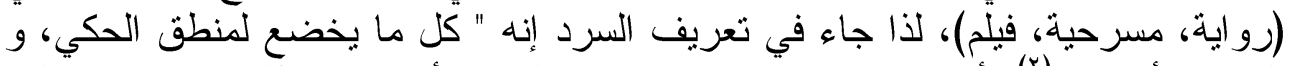

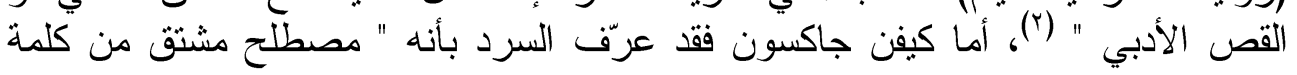
narration (narracion

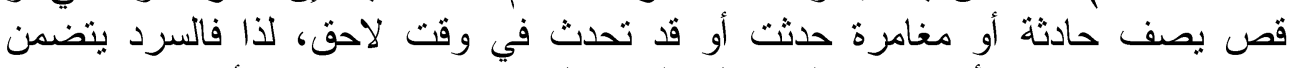

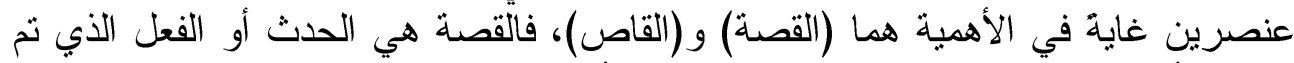

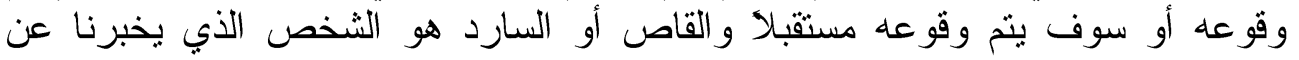
ذلك.

و قد عُرّن السرد كذلك على إنه " قص حادثة و احدة أو أكثر خيالية كانت أو حقيقية

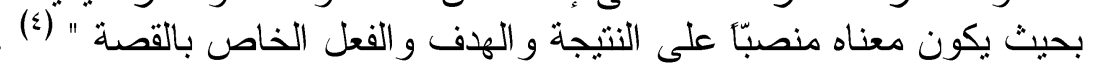

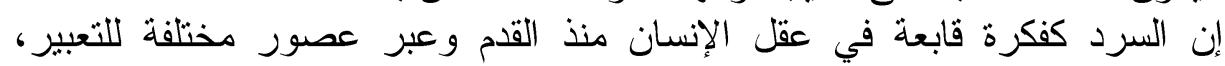

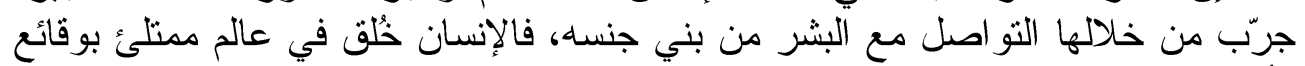

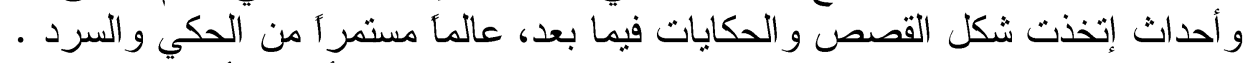

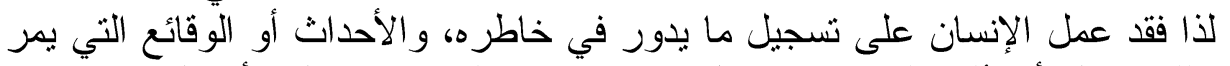

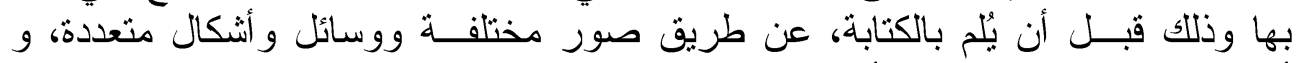

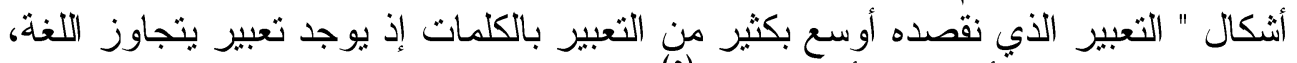

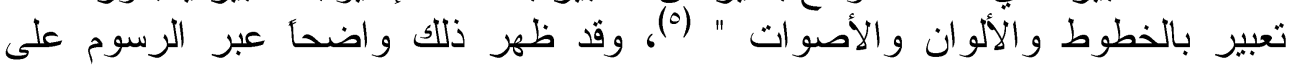

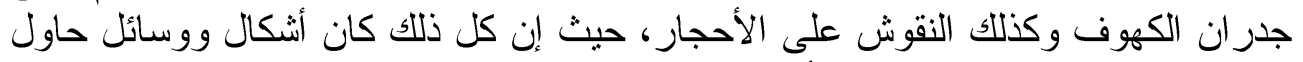

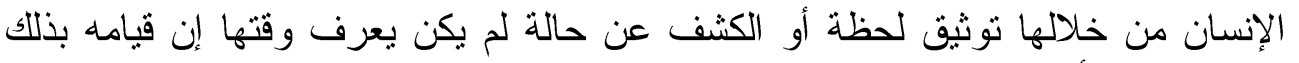

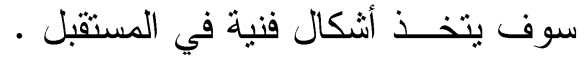

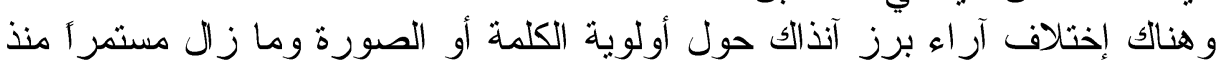

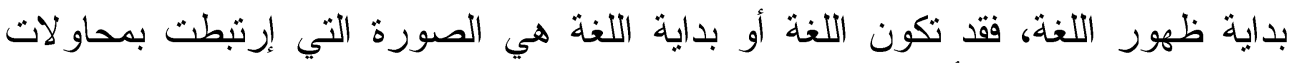

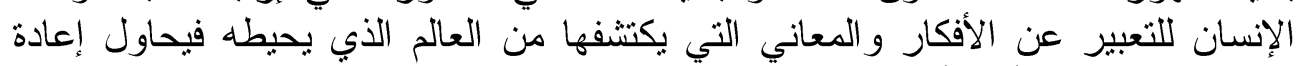

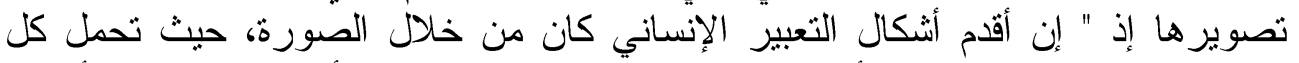

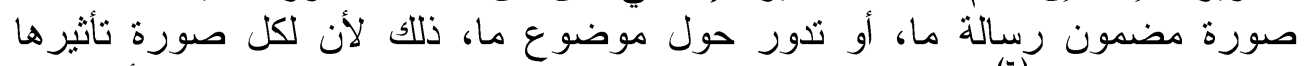

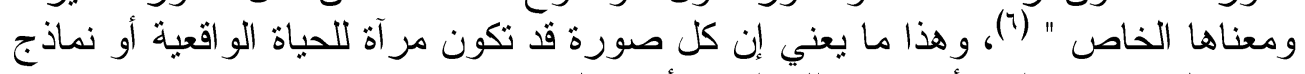

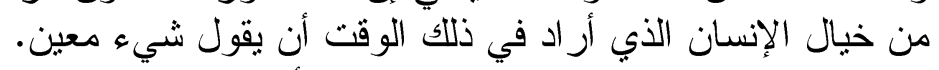

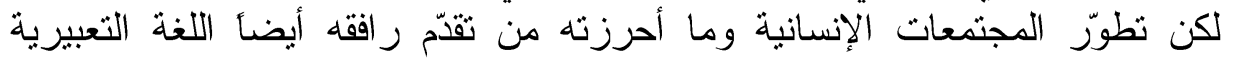

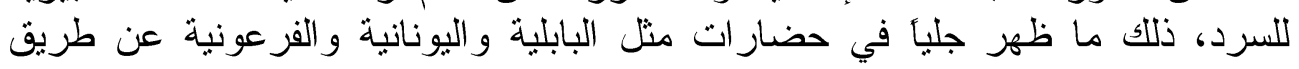

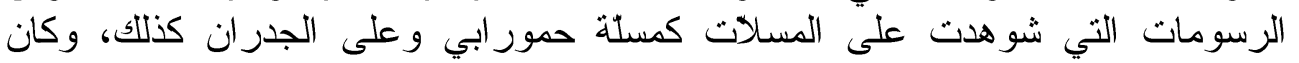

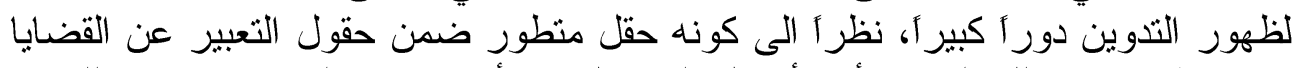

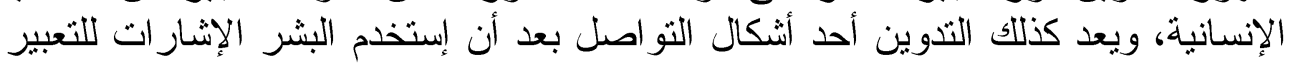

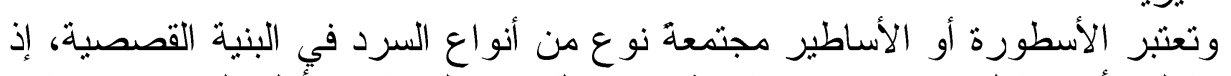

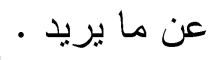

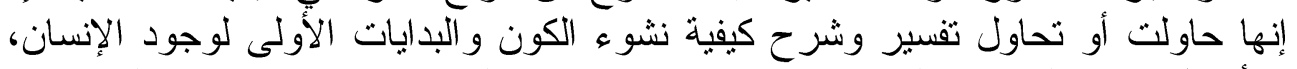

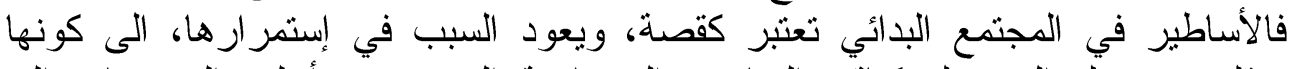

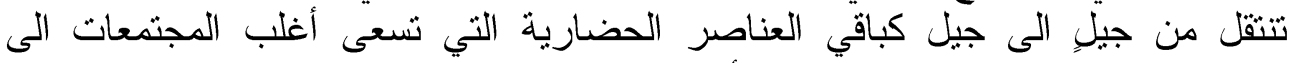

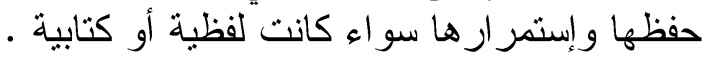




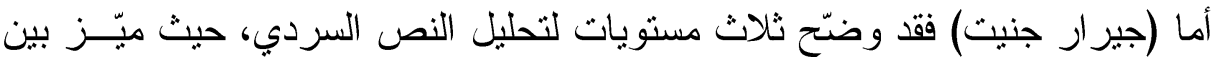

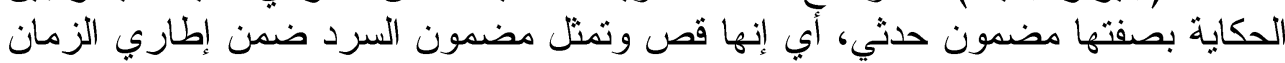

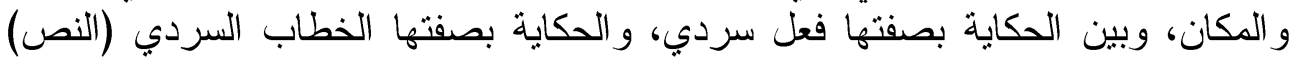

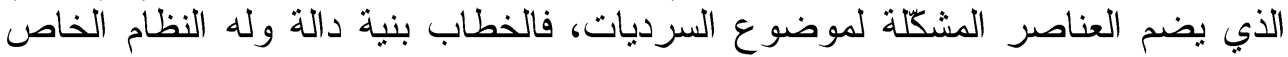
به و القو اعد الخاصة حسب المجال الذي يشغله، وقد بيّن (جيرار جنيت) ثلاثن مفاهيخ

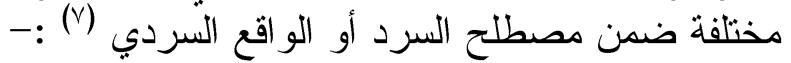

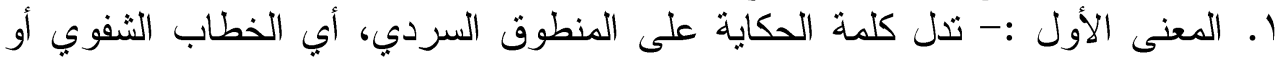
المكتوب، وهو الإستعمال الثائع الأكثر بداهية.

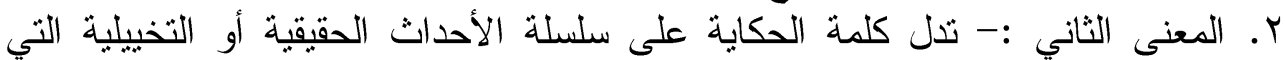

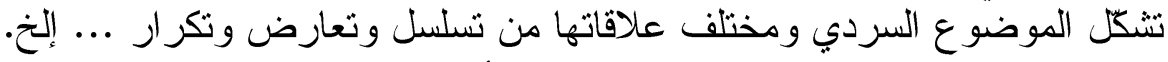

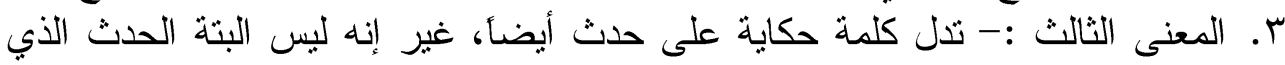

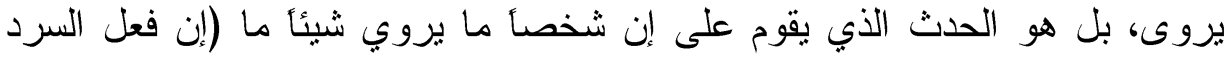
منتاول في حد ذاته). إن الجهود التي قد بذلت لمحاولة البحث عن قيمة وطبيعة الخطاب اللغوي في الأدب

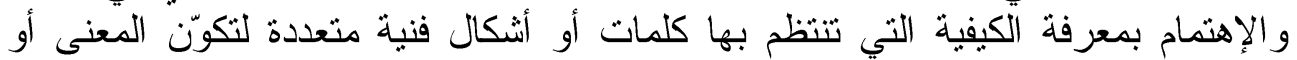

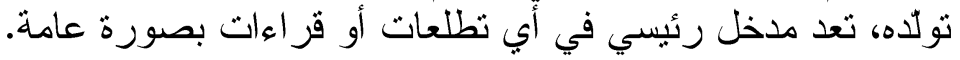

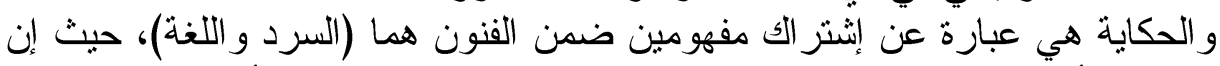

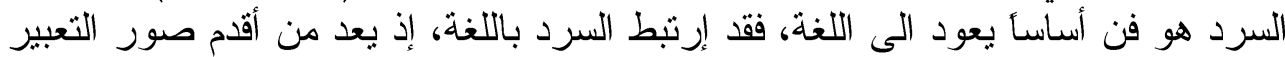

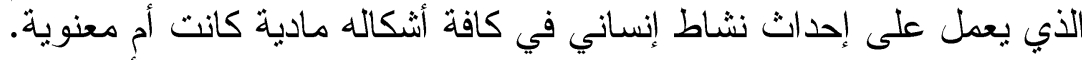

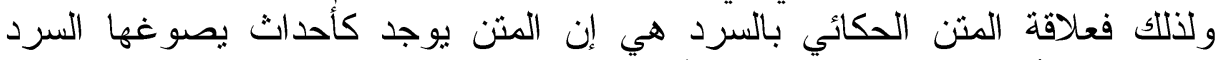

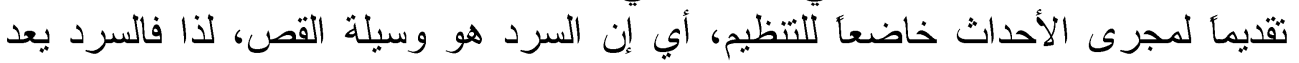

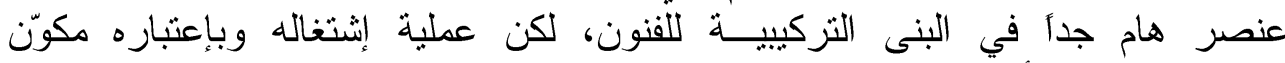

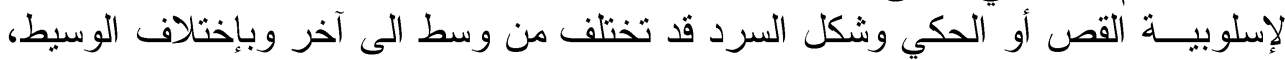

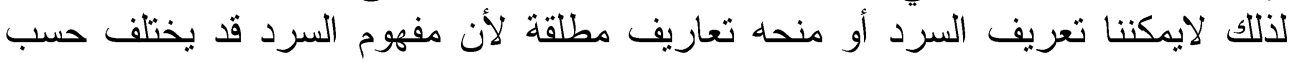

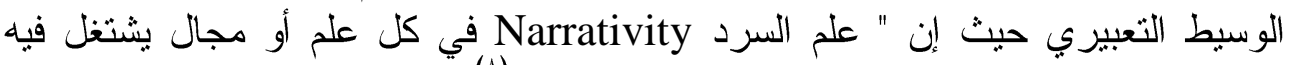

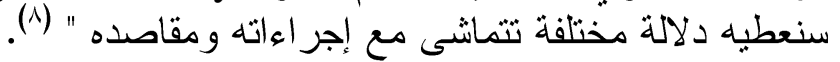

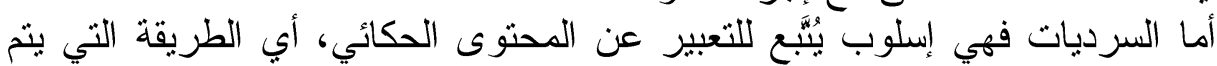

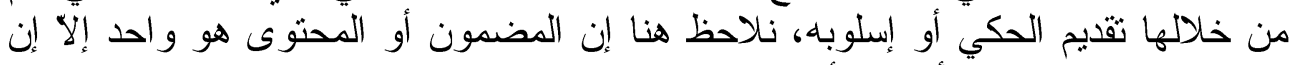

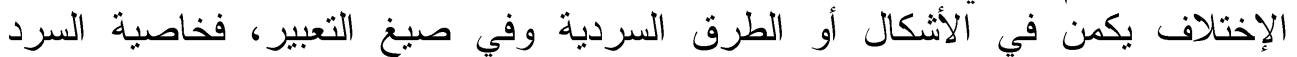

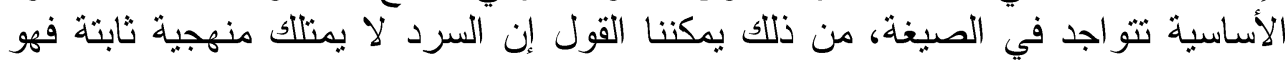

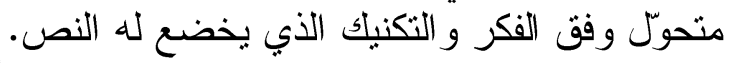

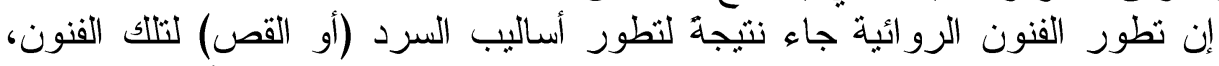

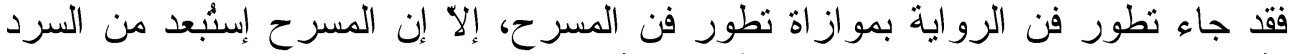

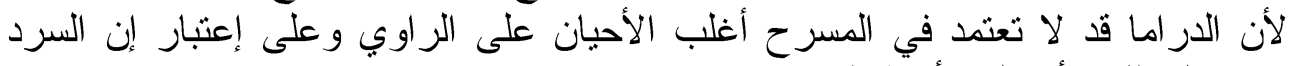

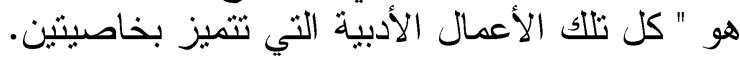

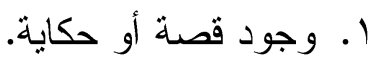

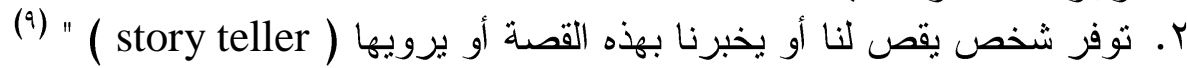
ومما لاشك فيه إن السرد يعد حجر الأساس الذي ترنكز عليه بنية النية الشكل الروائي . 


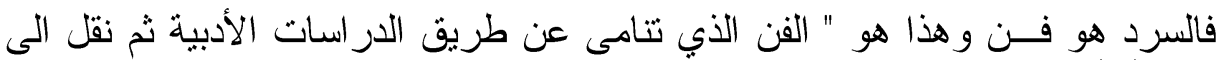

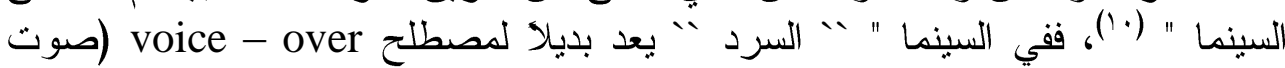

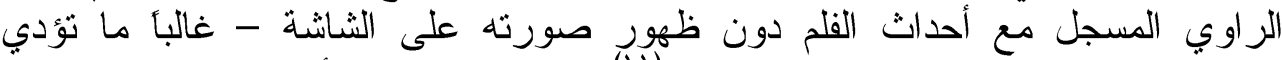

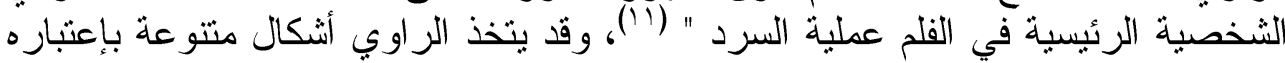
أحد التقنيات التي يعتمد عليها الكاتب (المؤلف) في بناء الأحداث وتنويع عرض تفاصليل

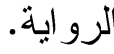

ولقد برزت العديد من المسمبات المتتوعة كمصطلح زاوية الرؤية و التي تتعلق بروئية الر اوي لما بر اه، أي حسب موقع الر اوي وز اوية نظره للأحداث، حيث قسّم الناقد

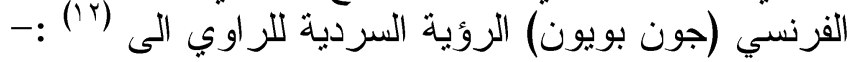

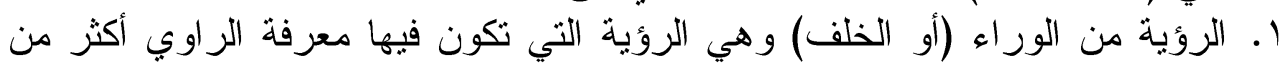
معرفة الثخصيات الرو الئية. r. الرؤية (مع): وهي الرؤية التي تتساوى فيها (أو تتصاحب)، معرفة الراوي بمعرفة الشخصيات الرو ائية. r. الرؤية من الخارج: وهي الرؤية التي تكون فيها، معرفة الراوي أقلَّ من معرفة الشخصيات الرو ائية.

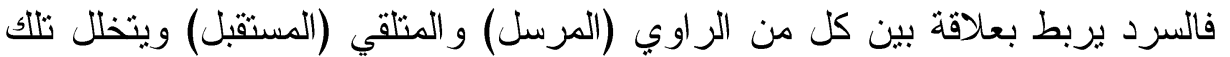

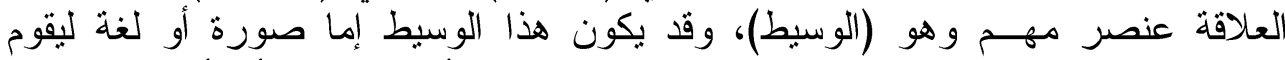

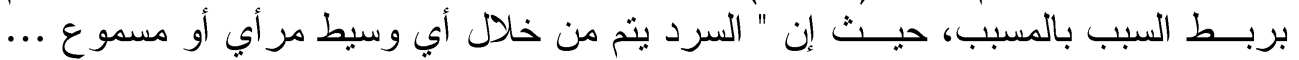

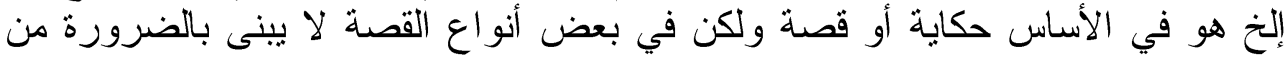

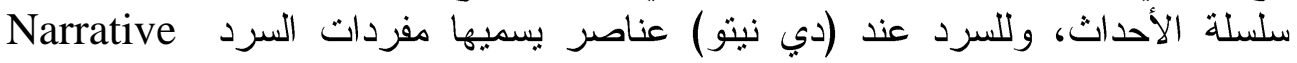

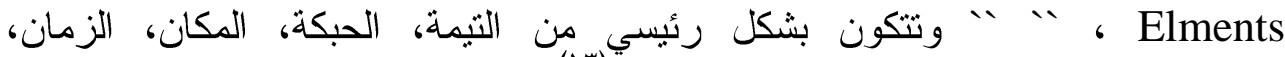

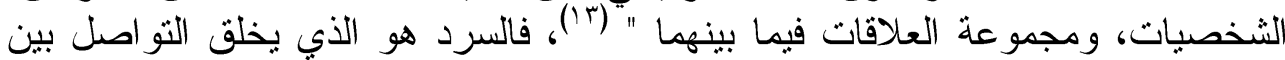

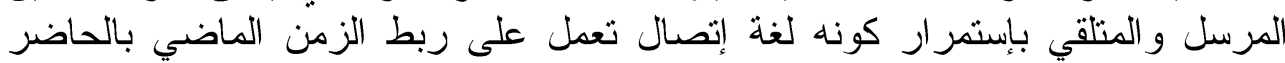

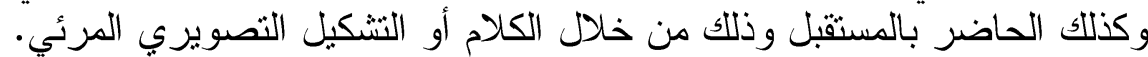

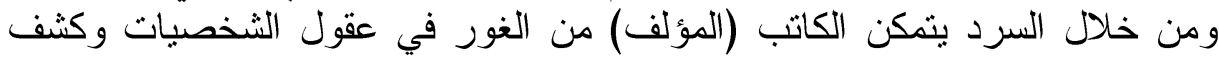

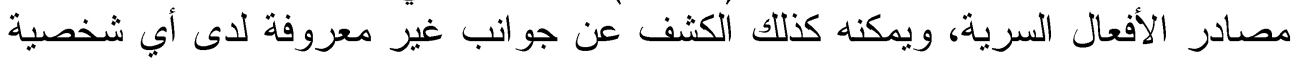

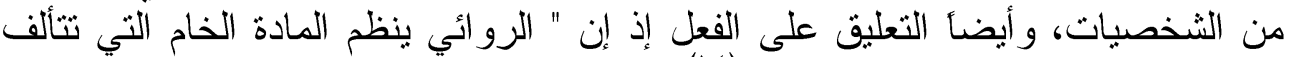

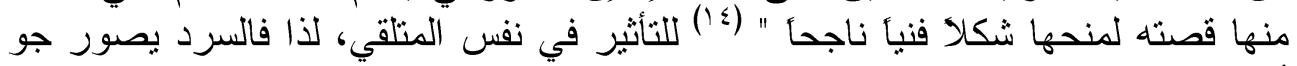

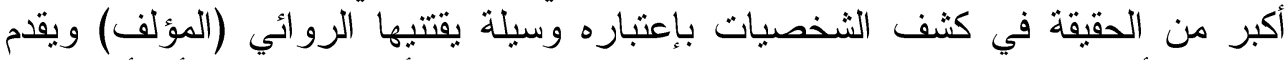

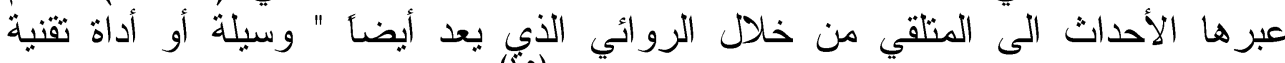

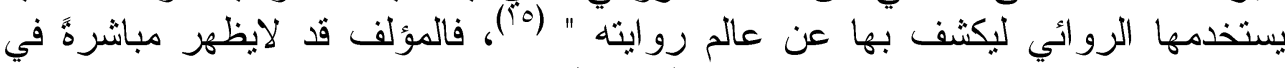
الرواية بل يقف خلف شخصية الراوي (السارد) ذلك ما يمكنه من التعبير عن رؤيته

أما ظهور السينما و التقدم و التطور الذي صاحبها و الذي عبرّ عنه تحول صور

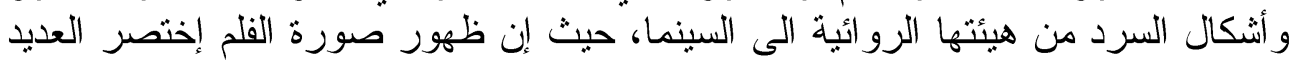

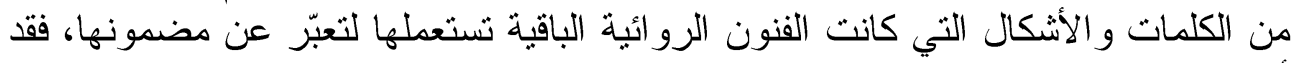

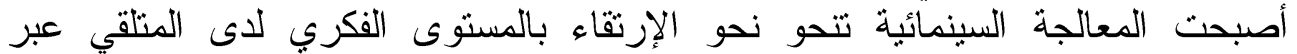

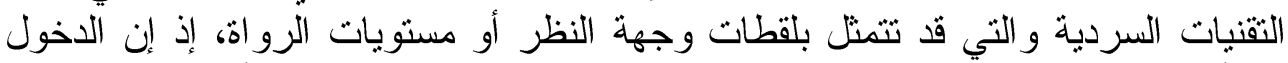
في أعماق نفس المتلقي وعرض ما في داخل ذهن الثخصية يعتبر ذا أهمية لا تقل عن أن الت 


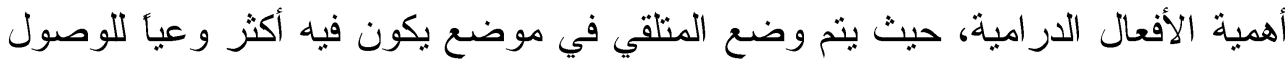

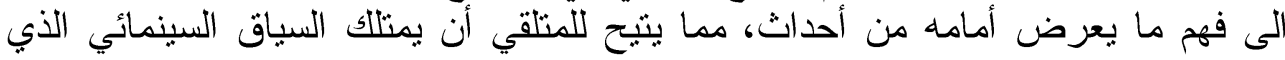

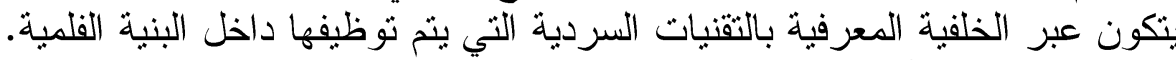

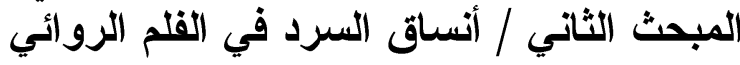

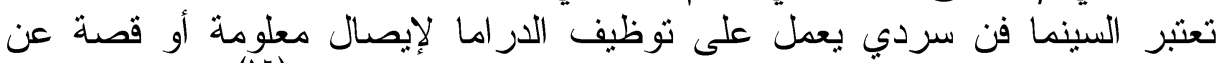

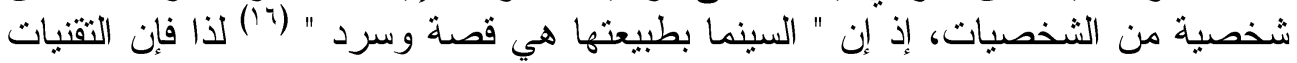

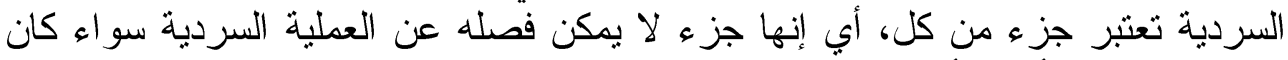
ذللك في رواية أدبية أم في فلم سينمائي، و الفن السينمائي بعتبر كباقي تقنيات التيات السرد

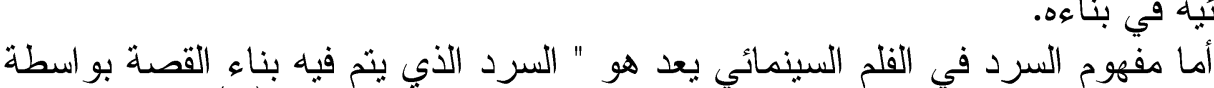

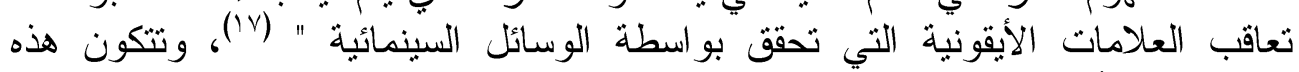

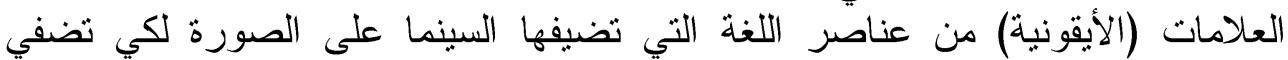

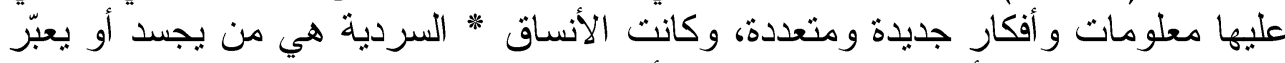

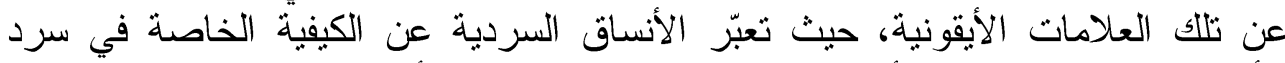

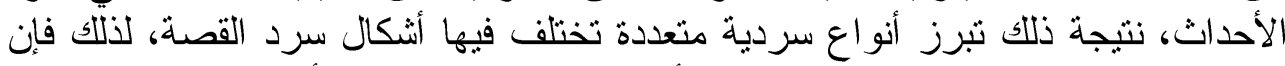
كل نسق سردي سيتطلب راوي (سارد) متأقلم معله، ويمكن تحديد الأنساق السردية بالن بالثكل

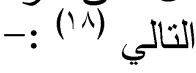

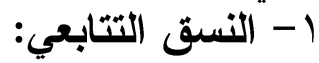

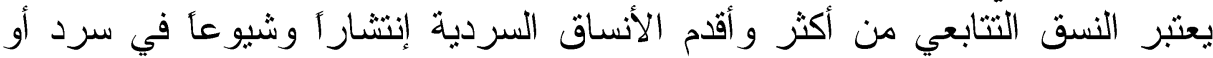

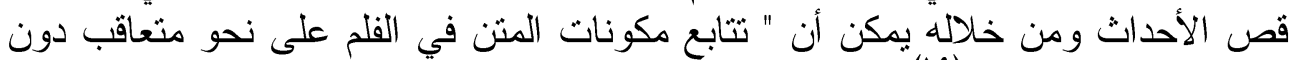

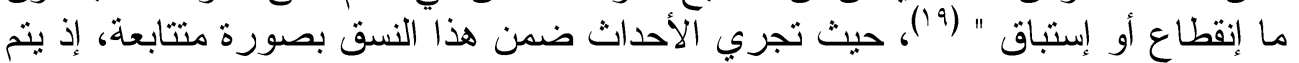

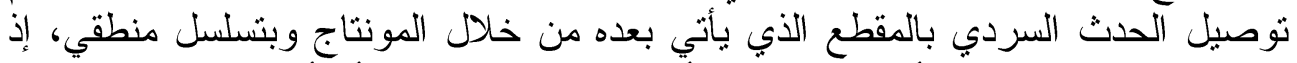

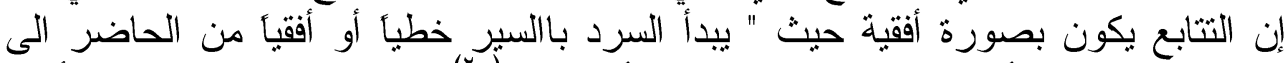

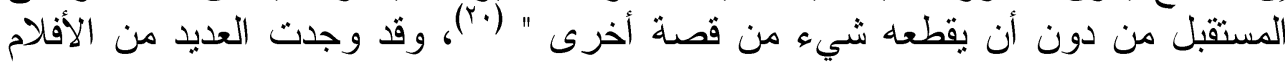

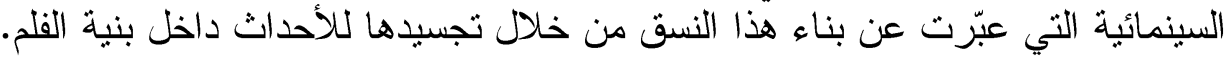

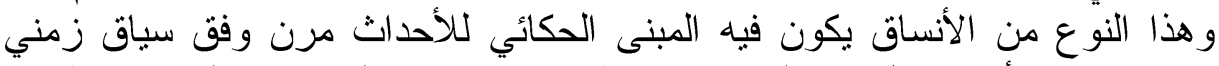

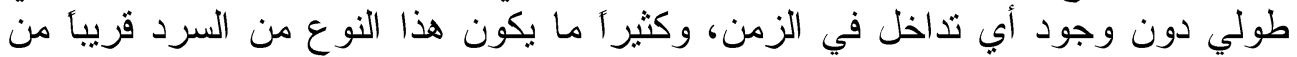

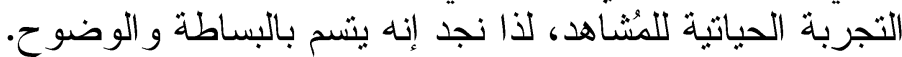

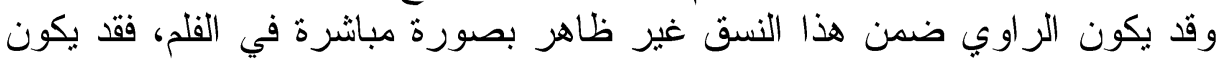

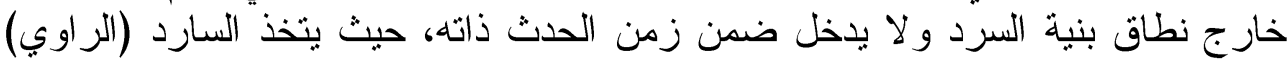

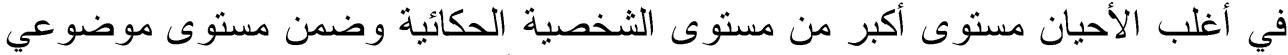

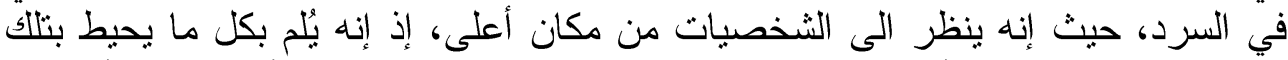

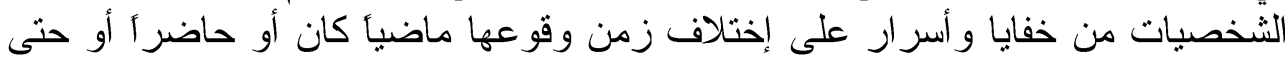

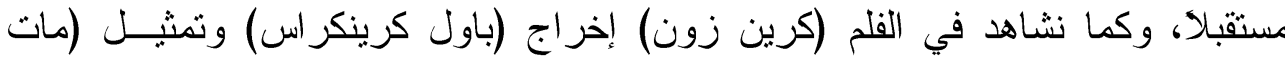

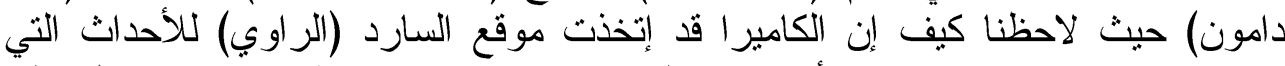

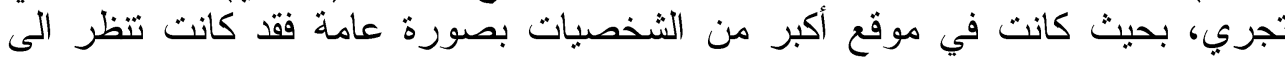

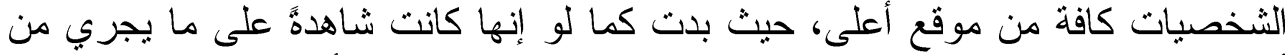

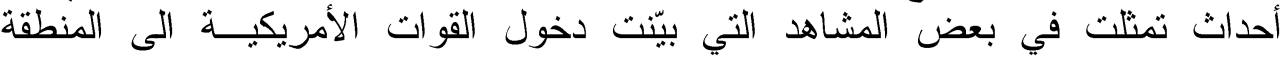


الخضراء، وبالتحديد عندما يذخل الجندي داخل القصر ليلتقي بأحد كبار المسؤلين الأمريكان، حيث لاحظنا تتبع الكامير التلألك الأحداث كما لو كان كانت هي التي تقوم بالسرد

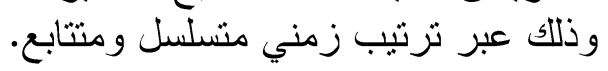
r - النسق السردي المتذاخل:

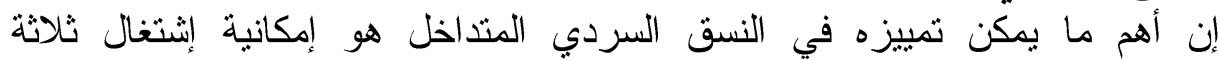

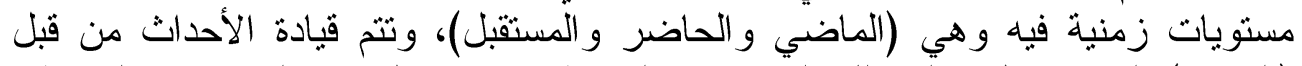

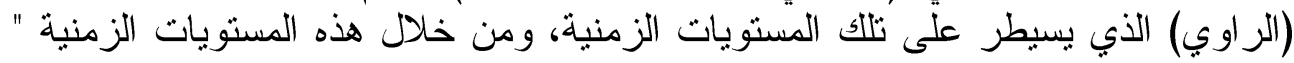

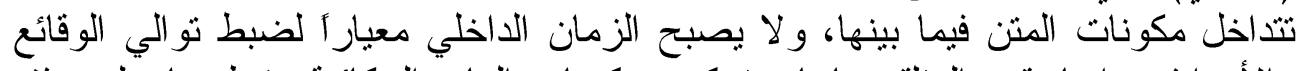

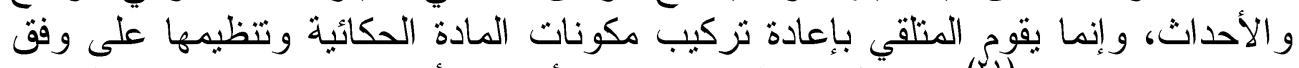

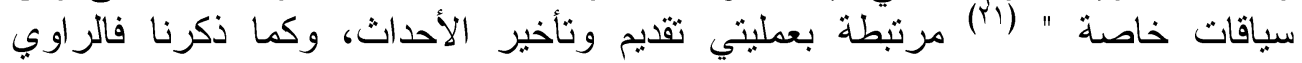

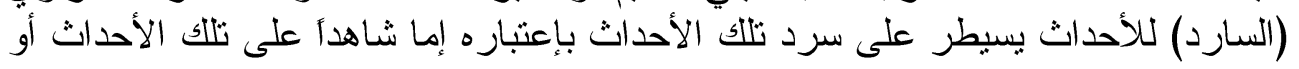
مشاركأ فيها.

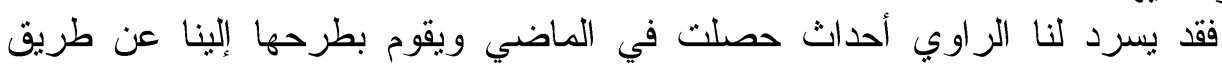

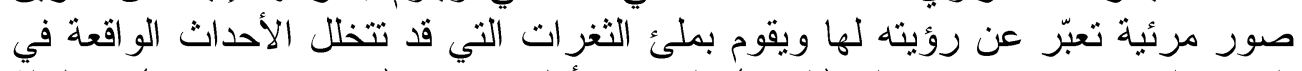

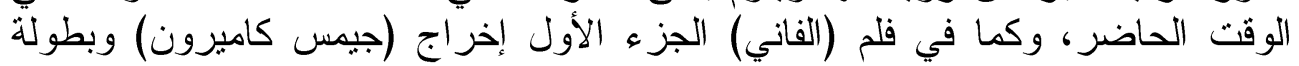

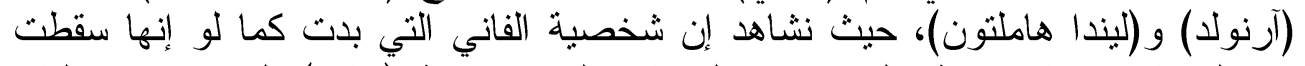

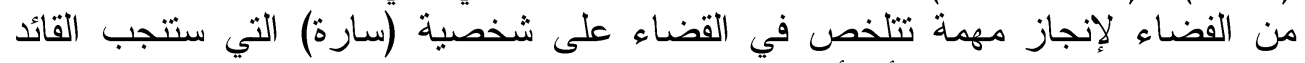

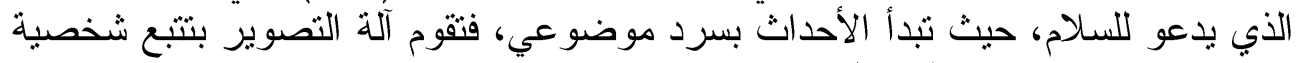

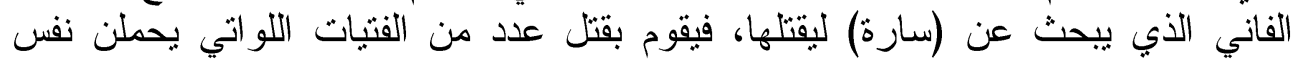

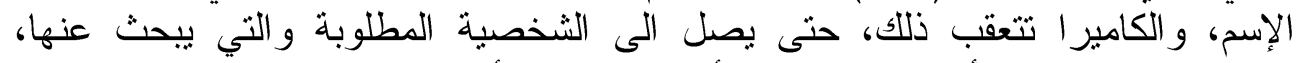

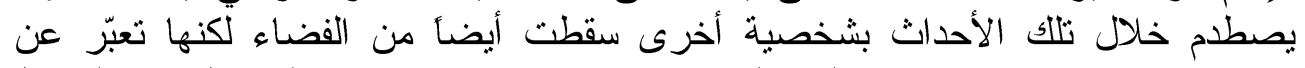

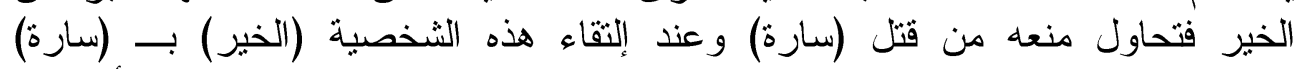

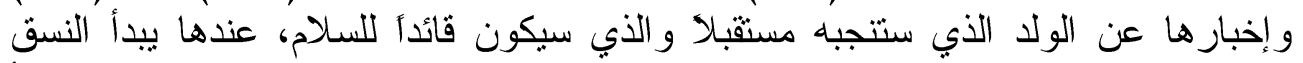

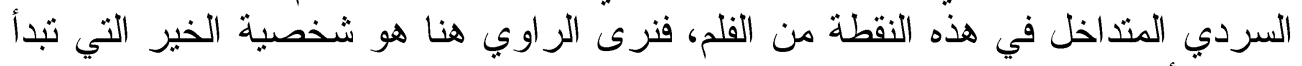

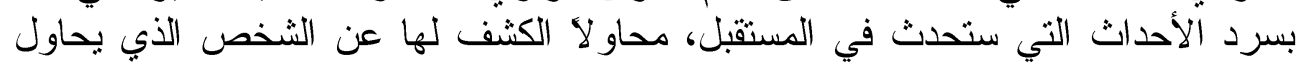

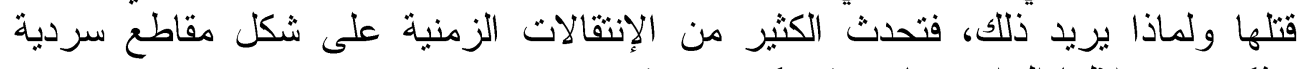

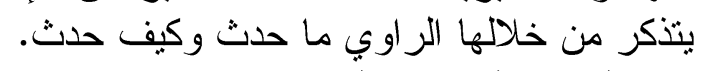

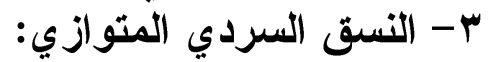

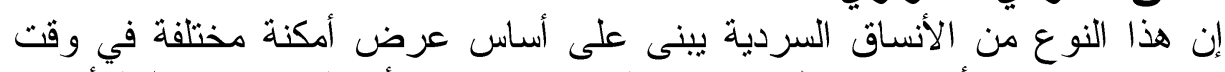

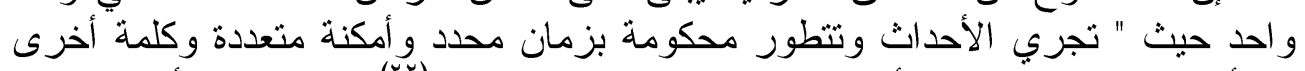

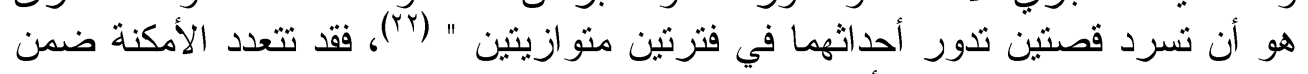

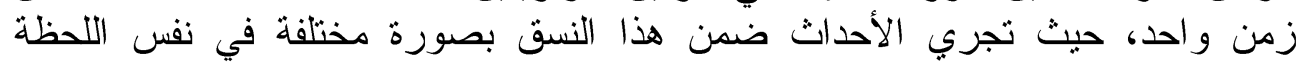

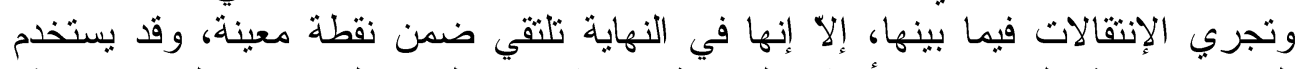

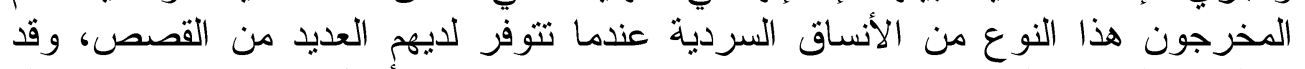

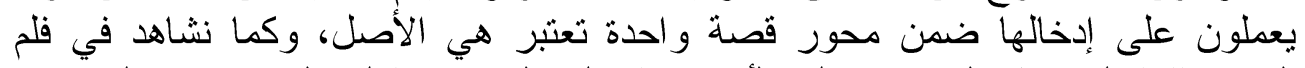

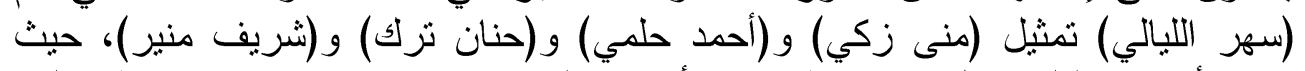

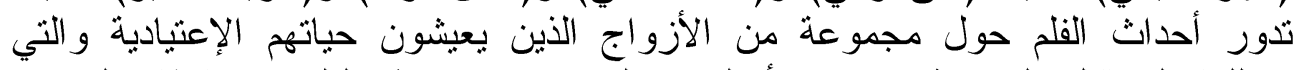

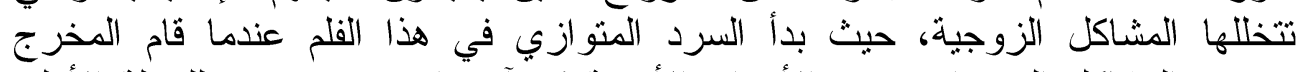

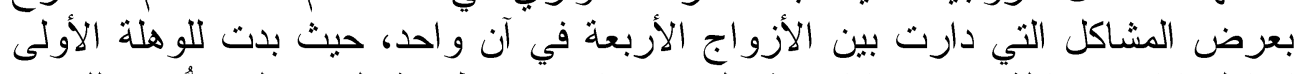

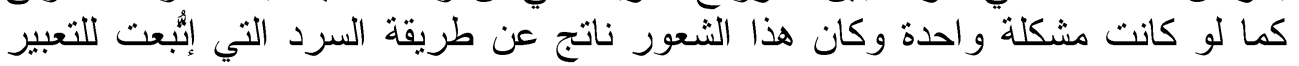


عن تللك المشاكل، حيث إن الإنتقالات من زوجين الى زوجين آخرين أعطت شعور

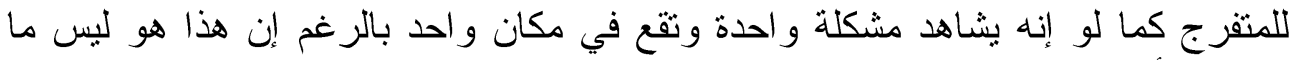

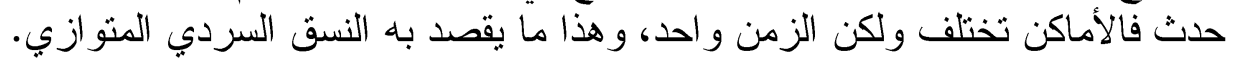

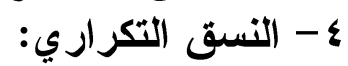

يقترب هذا النوع من الأنساق السردية نوعأ ما الى نسق التتابع لكنه قد يتميز عنه في

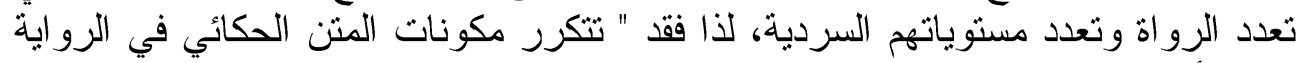

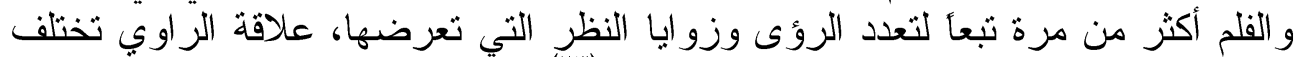

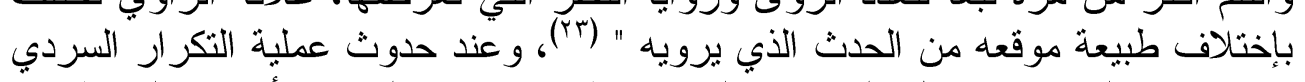

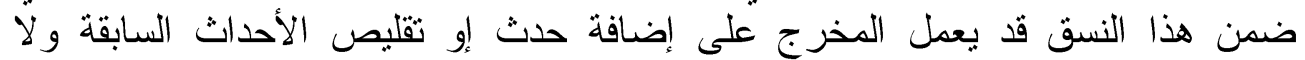

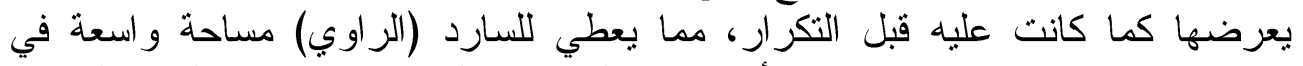

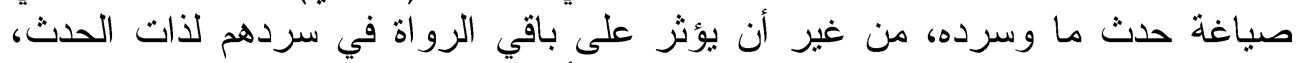

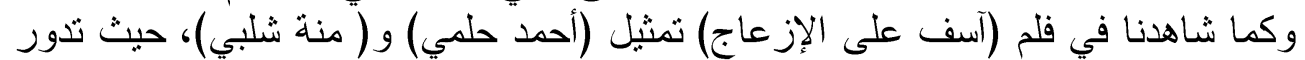

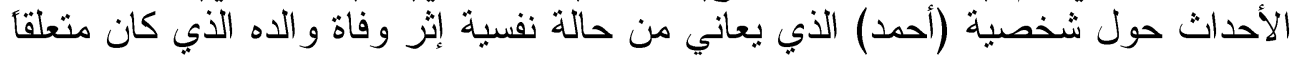

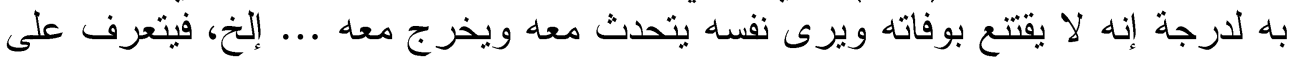

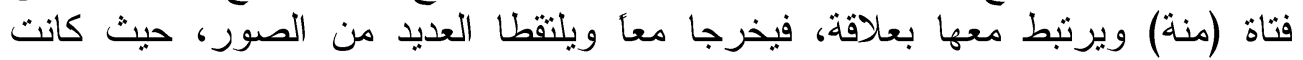

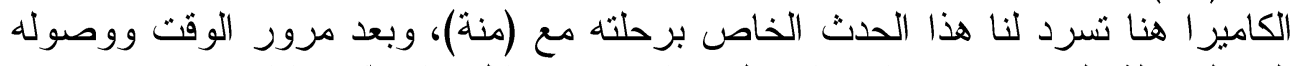

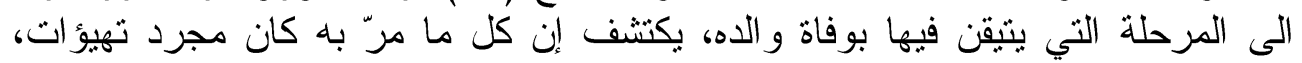

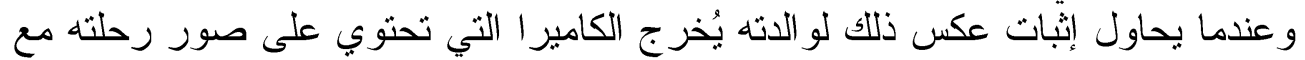

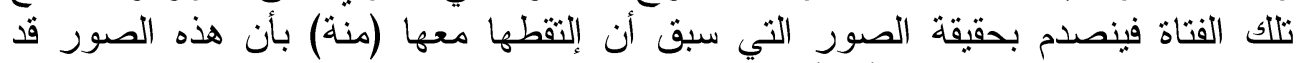

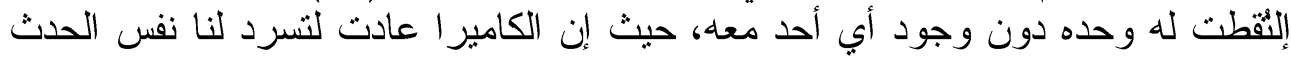

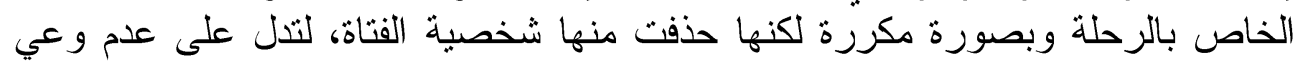
شخصية البطل (أحمد).

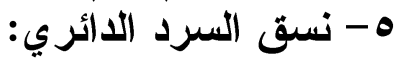

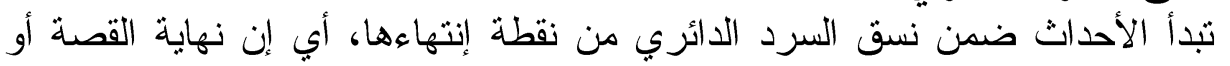

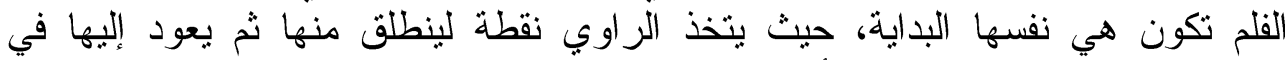

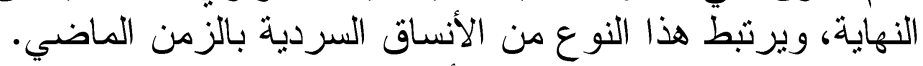

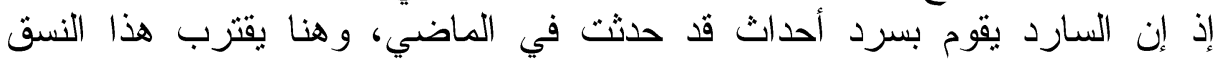

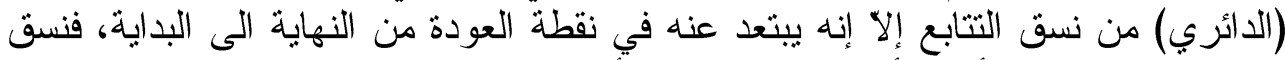

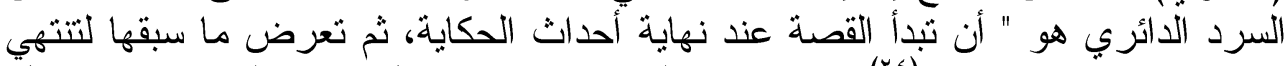

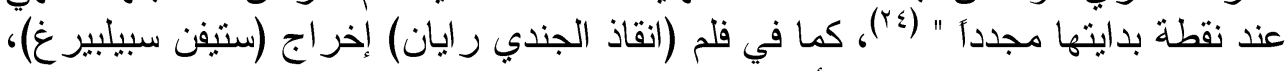

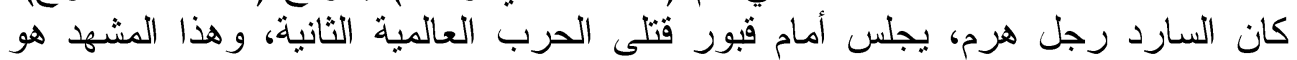

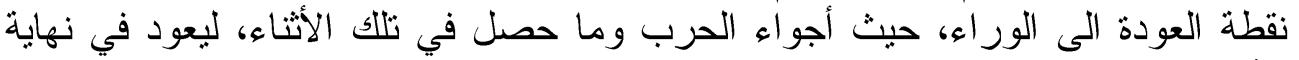

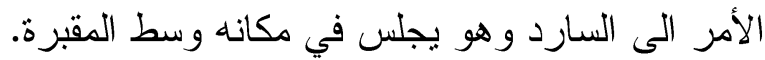
المبحث الثالث / خصوصية الَّرد الوثنائقي في الفيلم الروائي

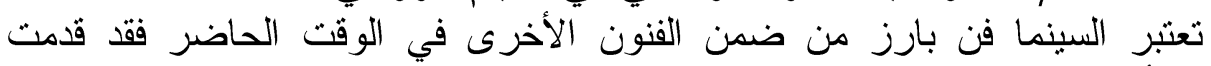

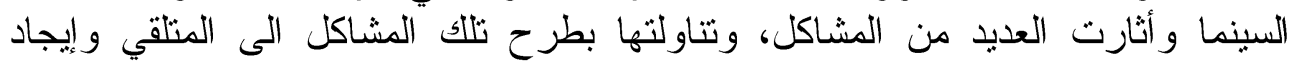

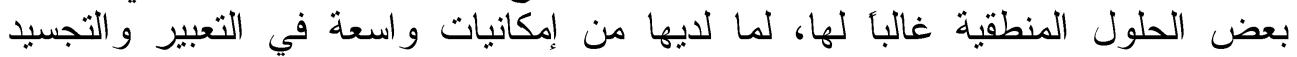

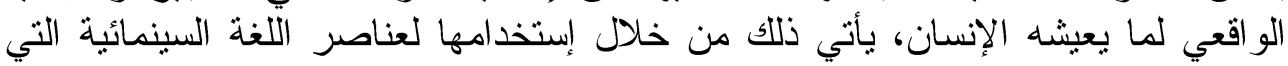


تعتبر قاسما مشتركأ ما بين الفلم الرو ائي و الفلم الوثائقي، إلا إن الإختلاف الحقيقي في هذا

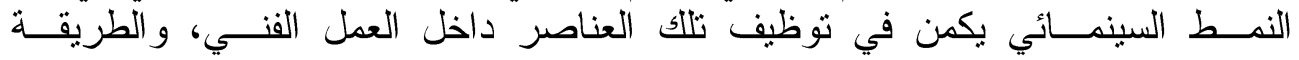

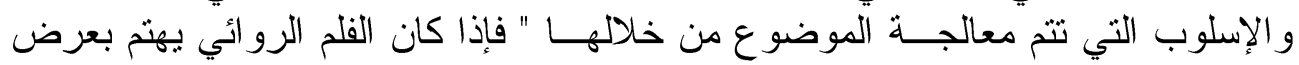

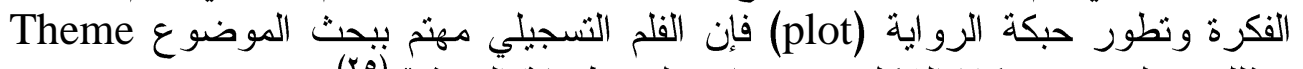

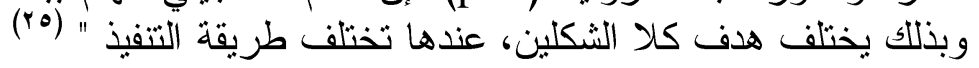

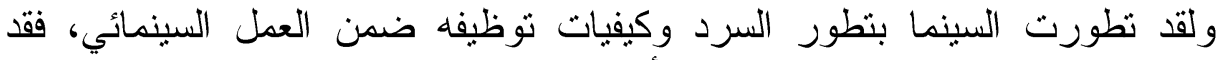

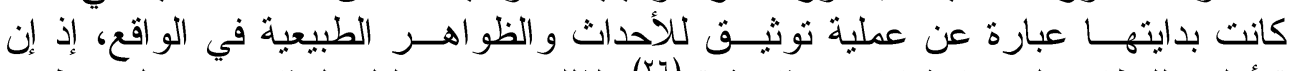

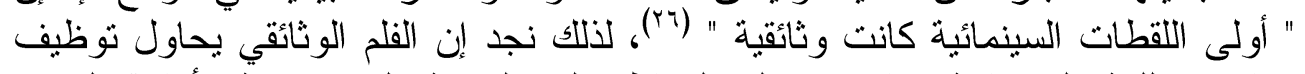

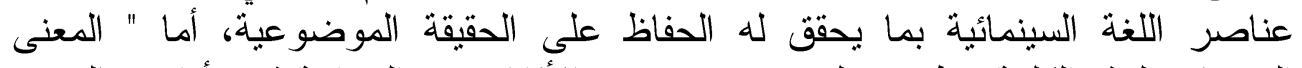

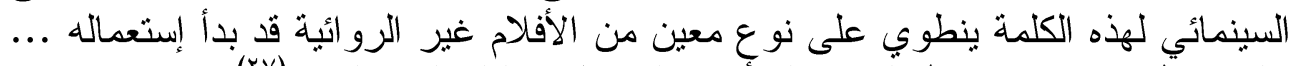

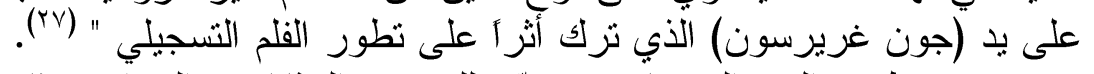

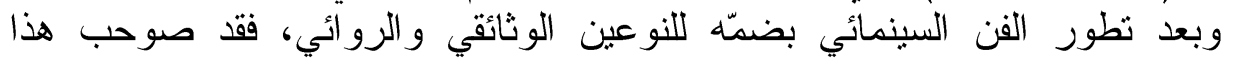

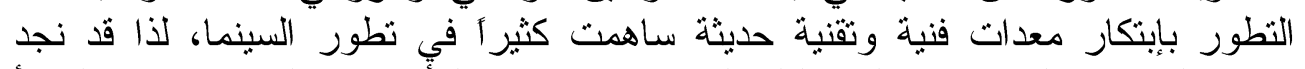

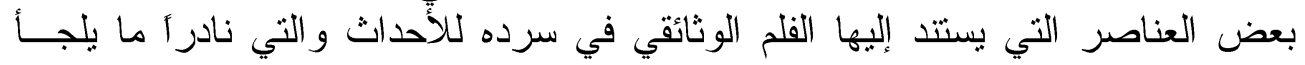

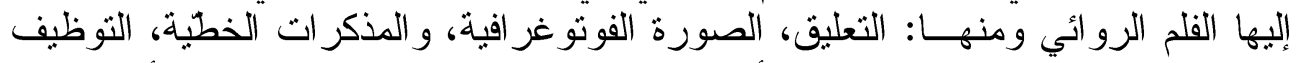

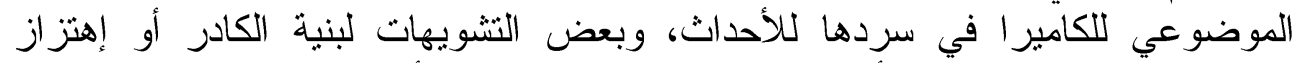

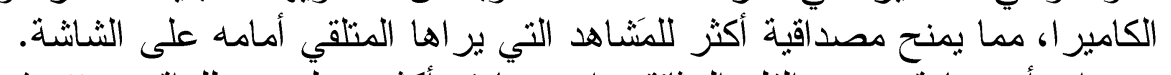

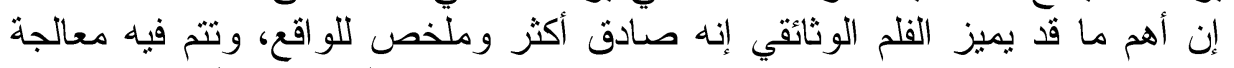

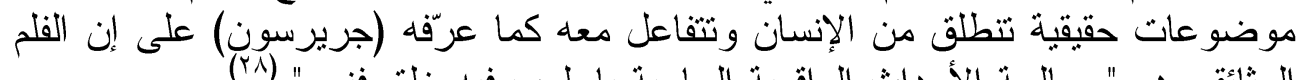

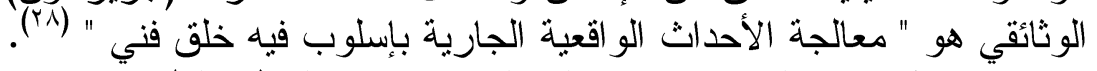

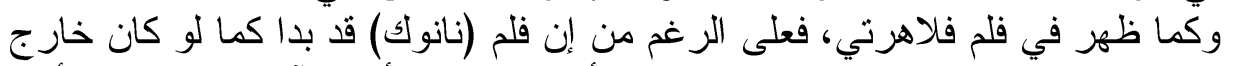

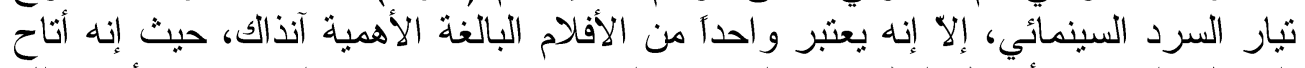

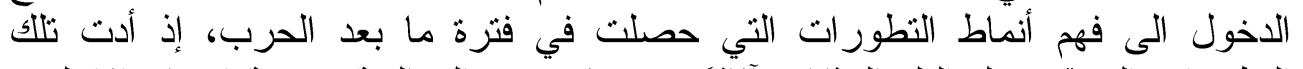

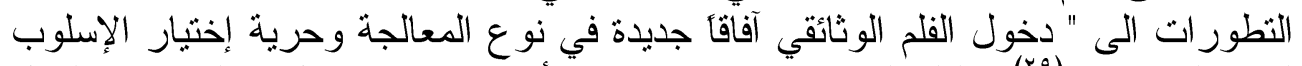

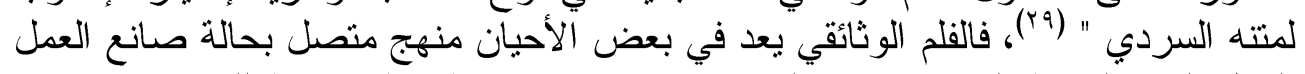

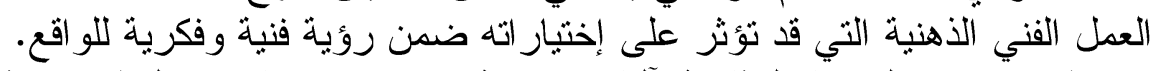

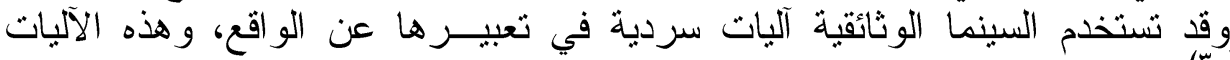

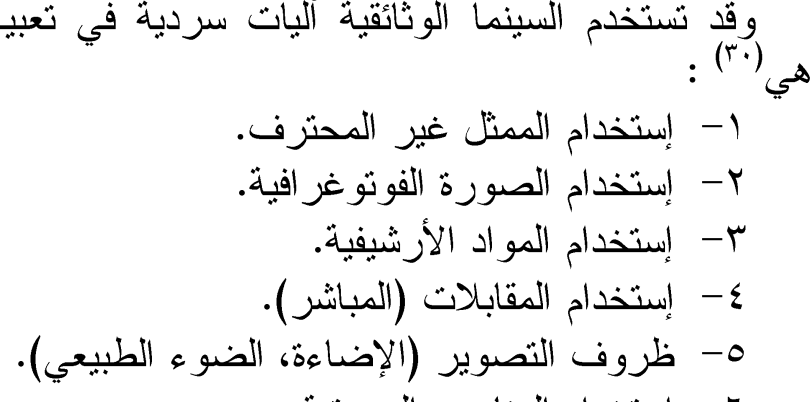

צ- إستخدام العناصر الصوتئة

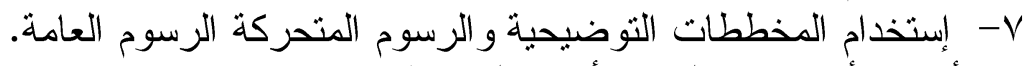

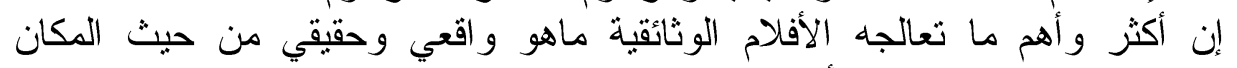

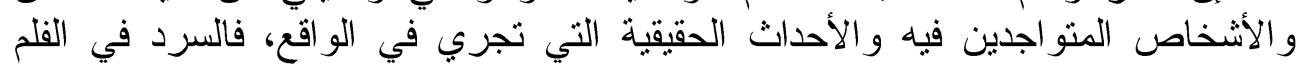

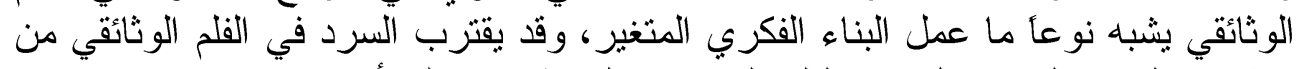
عناصر السرد التي تعمل في الفلم الروائي، بل وقد يشترك وفي أو بتنق معه في إبتخدام 
بعض العناصر ومنها الرواة، وهذا ما يثيح التداخل ضمن أساليب الفلم الروائي و الفلم

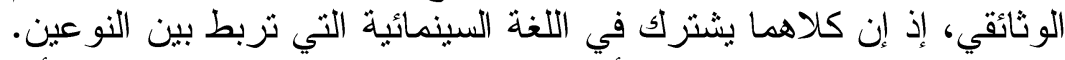

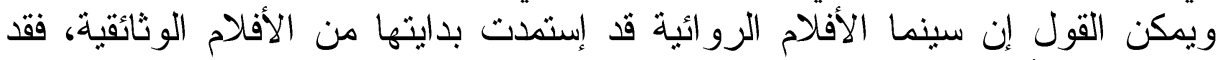

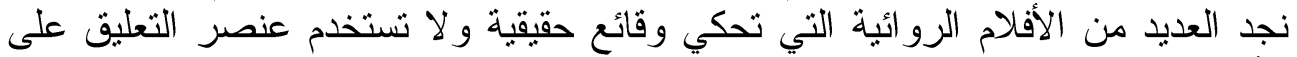

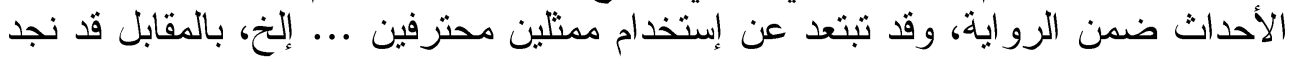

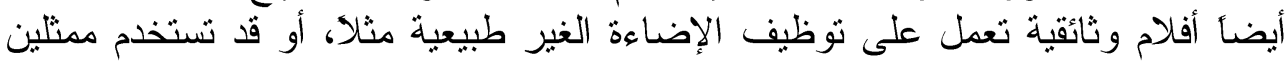

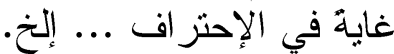

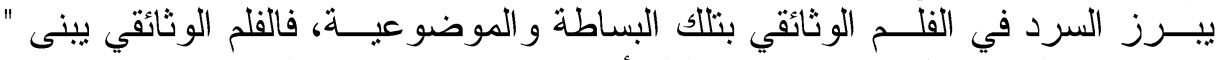

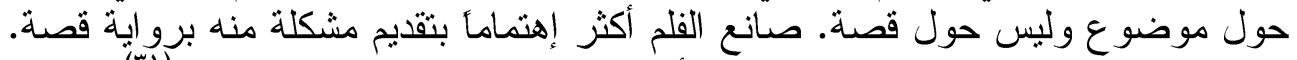

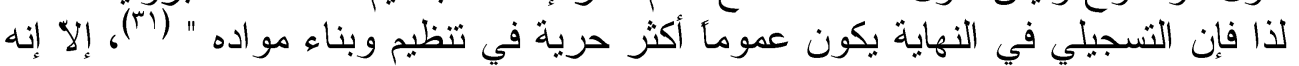

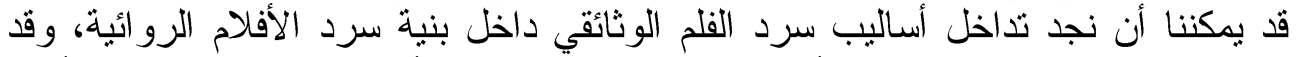

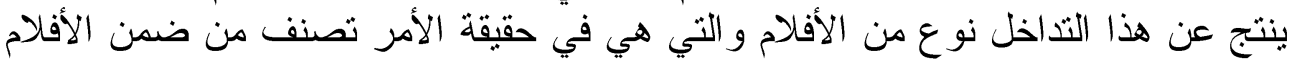

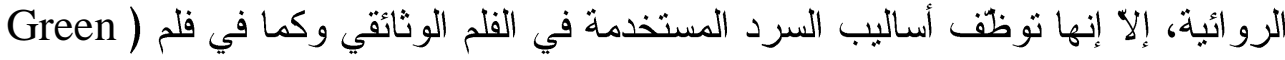
Zone

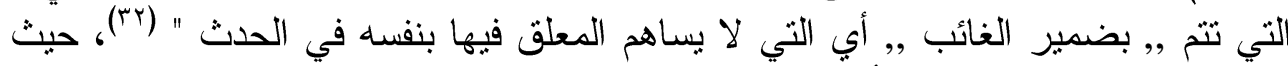

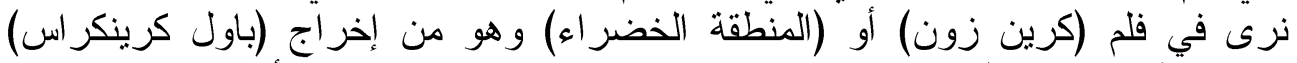

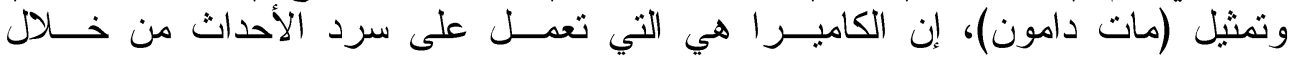

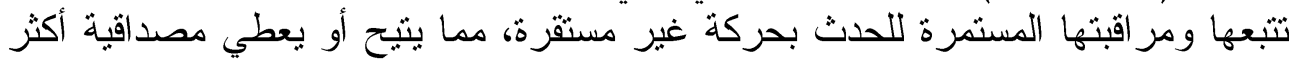

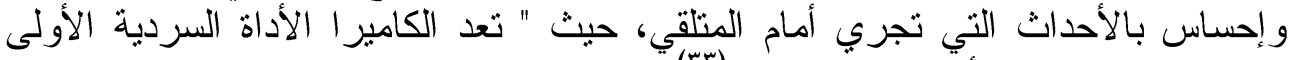

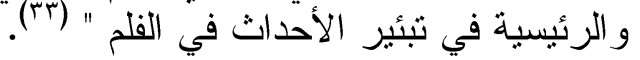

فالكامير| تضيف للسرد الصوري ديناميكية وفعالية كبيرة ومؤثرة، وهذا النوع من

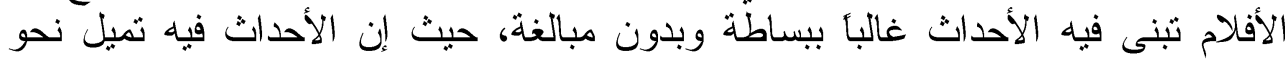

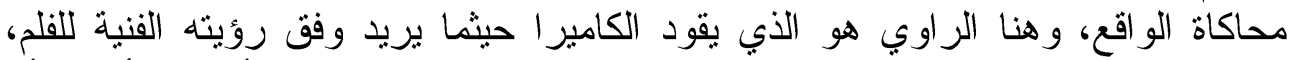

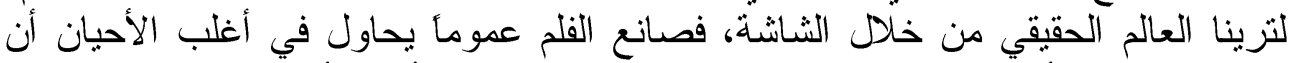

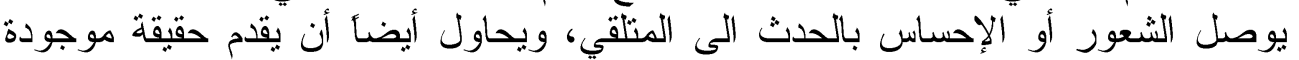

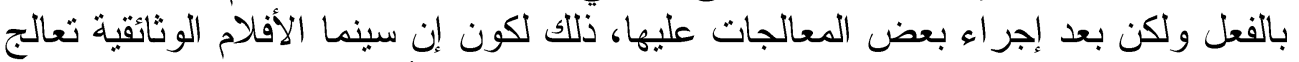

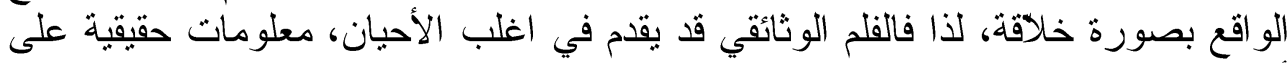

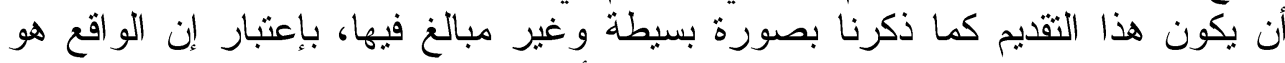

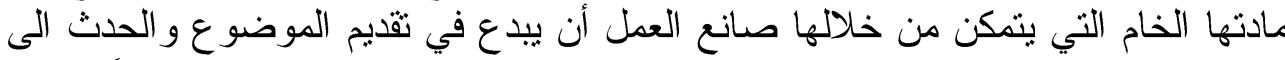

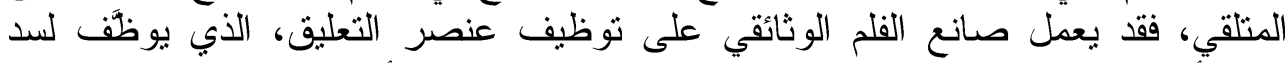

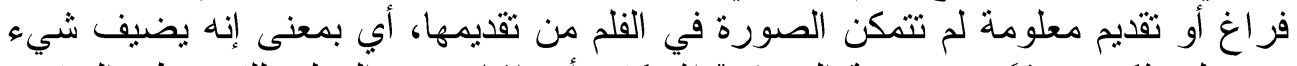

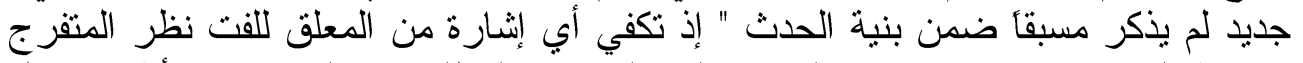

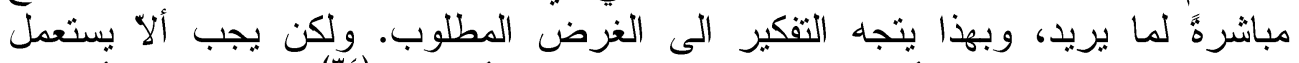

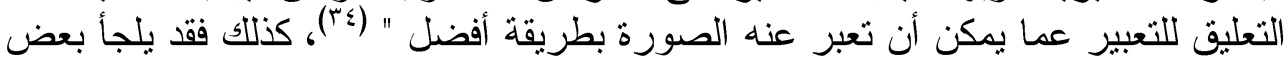

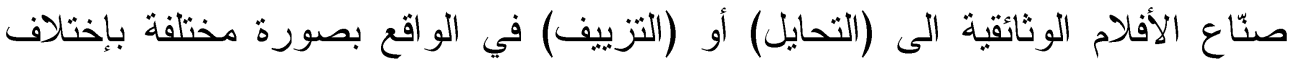

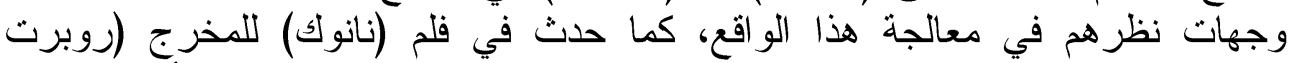

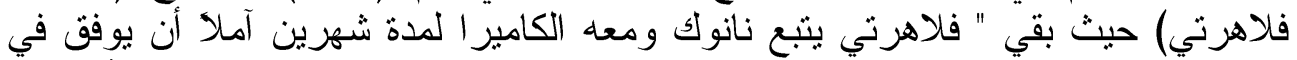
تصوير نانوك وهو يرشق عجلا بحربته من فتحة في الجليد. و إضطر في نهاية الأمر إلى إنى 


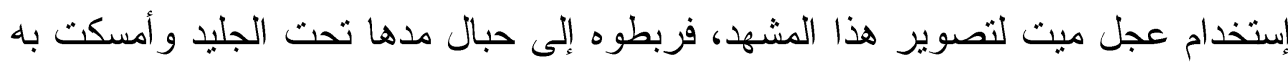

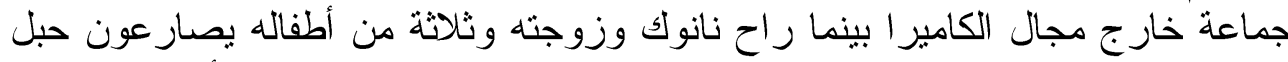

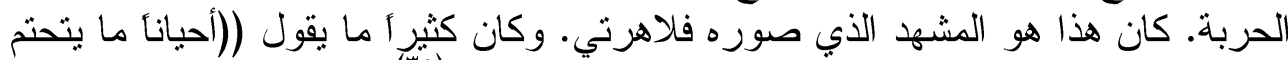

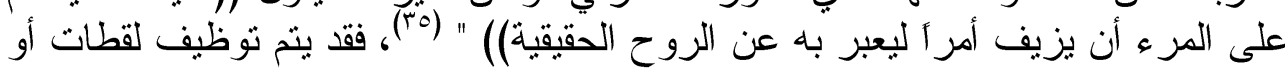

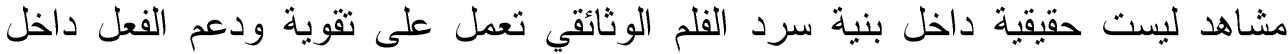

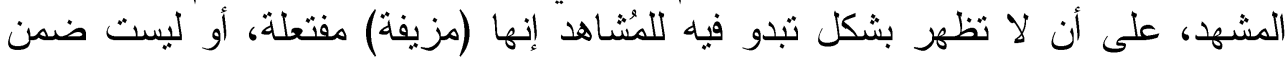

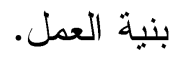

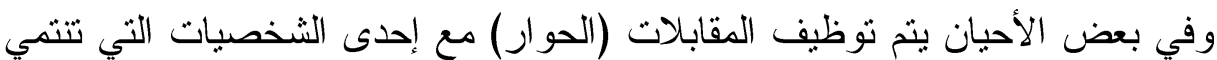

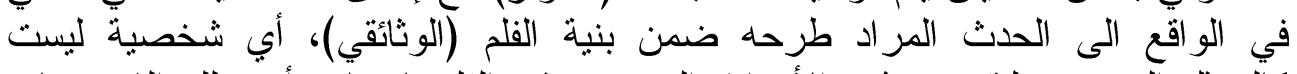

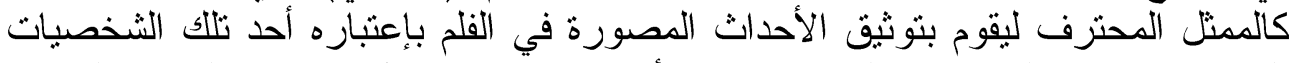

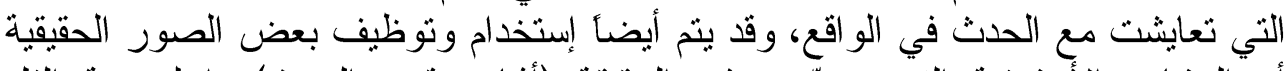

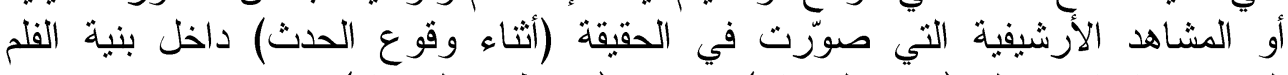

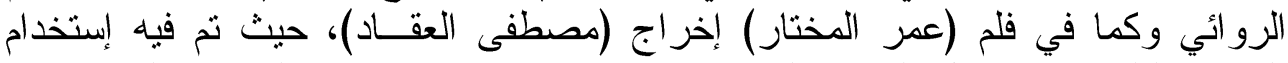

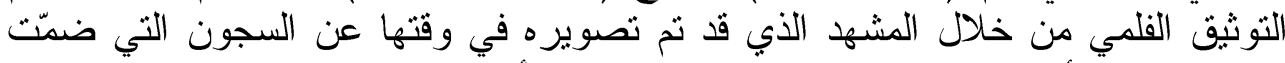

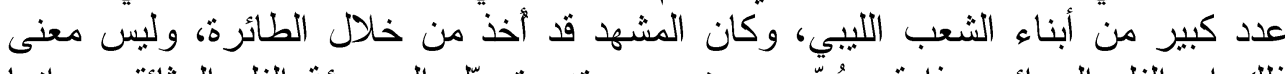

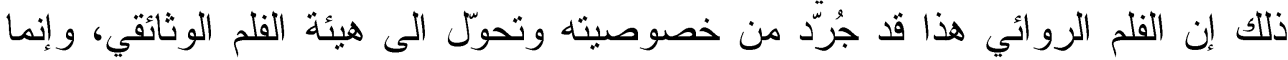

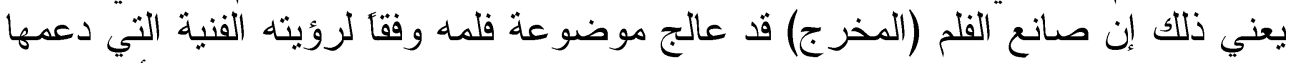

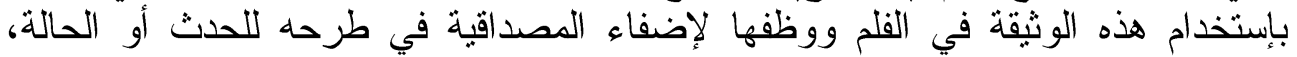

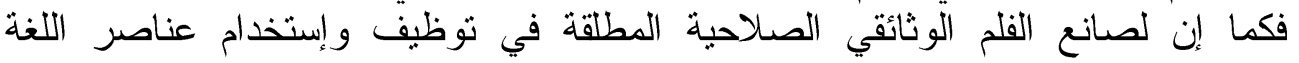

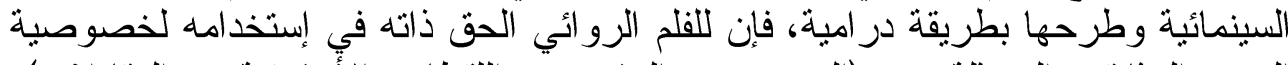

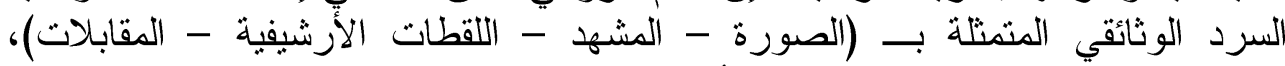

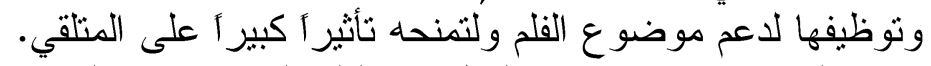

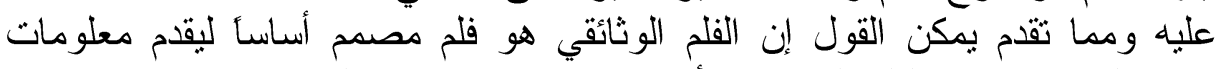

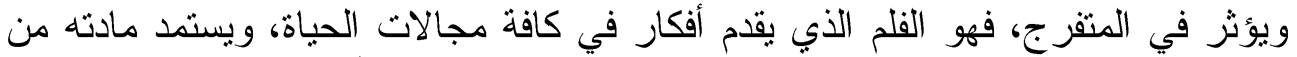

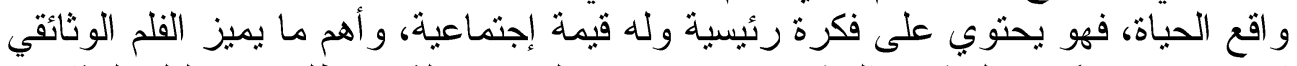

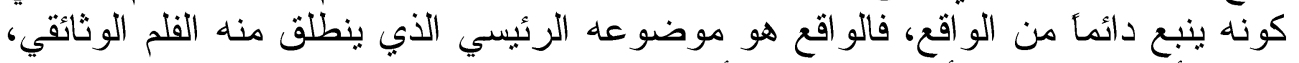

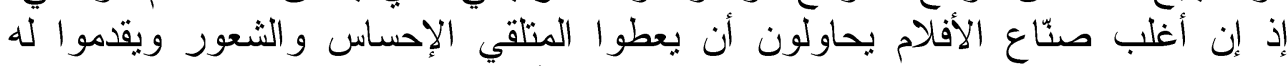

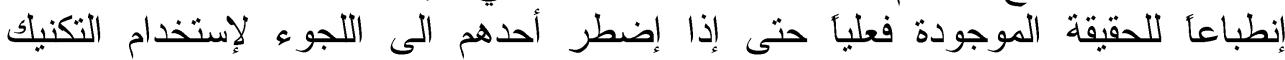

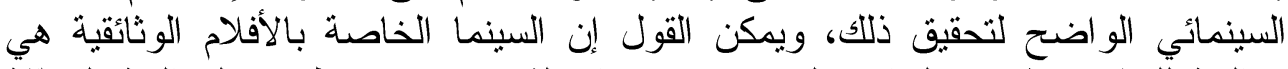

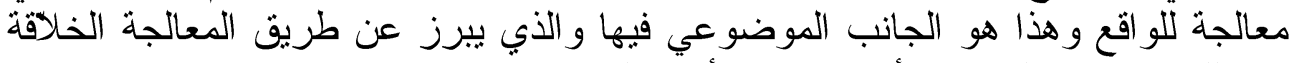
فيها للو اقع، وهو الجانب الأساسي في الأفلام الوثائقية.

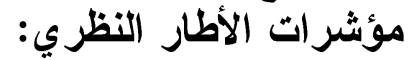

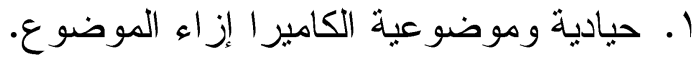

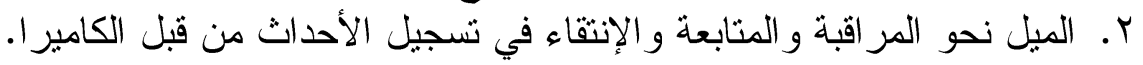

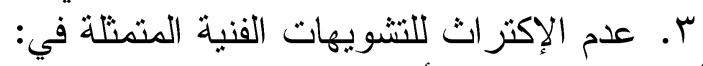
أ- إستز از الكامير أو أو ميلانها. ب- عدم الإهتمام بالبناء التشكيلي و التكويني.

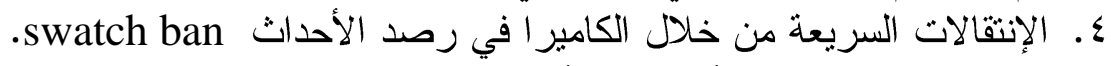
0. عدم المبالغة في بنية الأحداث و الأداء التمثيلي. 


\section{الفصل الثالث (اجراعات البحث)}

سيعتمد الباحث المنهج الوصفي الذي بتضمن التحليل بإعتباره أنسب المناهج لتحليل

$$
\text { منهج البحث: إنمد }
$$

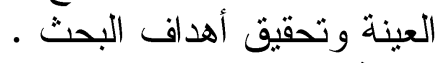

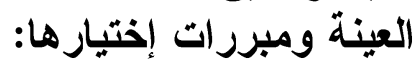

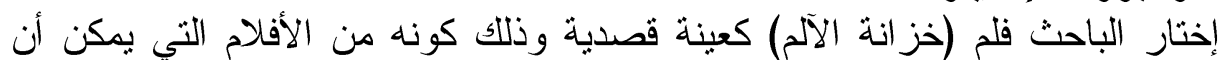

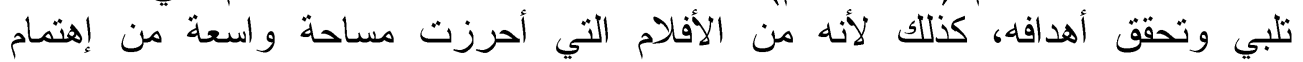
المشاهدين و المهتمين بالسينما و نقادها.

أداة التحليل:

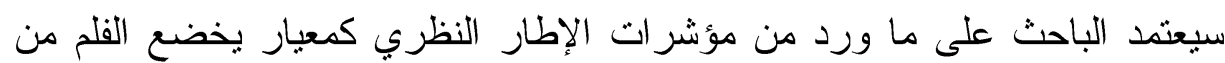

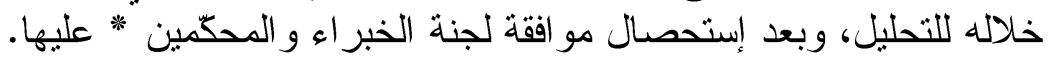

وحدة التحليل:

سبعتمد الباحث المشهد كوحدة للتحليل لغرض الوصول اللى مضمون عينة فلمه كونه

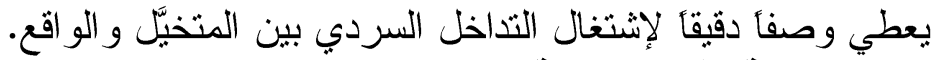

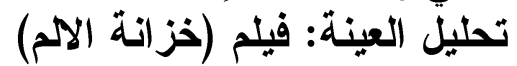

تدور أحداث الفلم (خزانة الألم) حول مجموعة من الجنود الأمريكان المنو اجدين

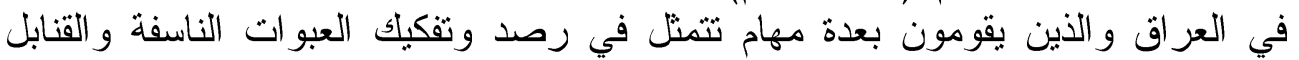

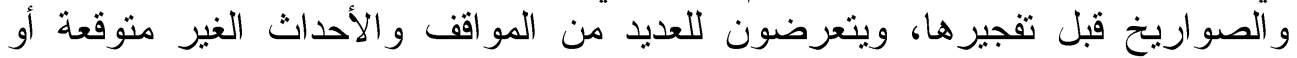

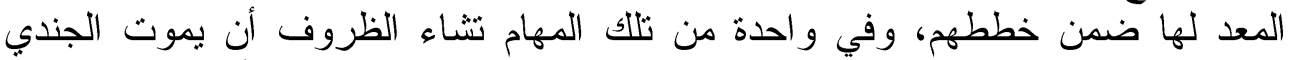

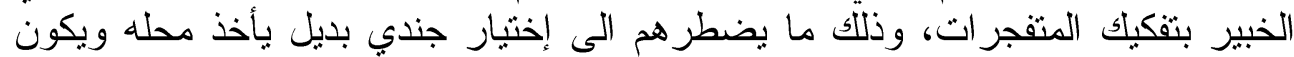

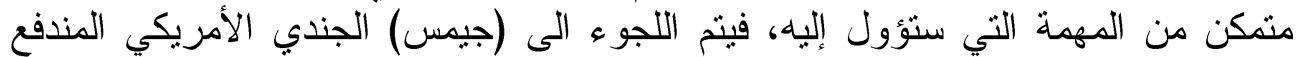

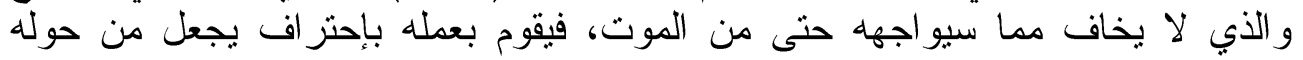

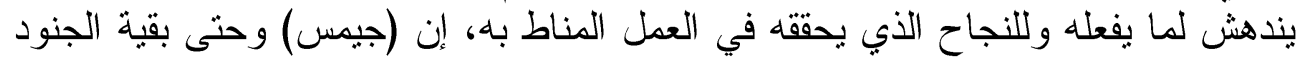

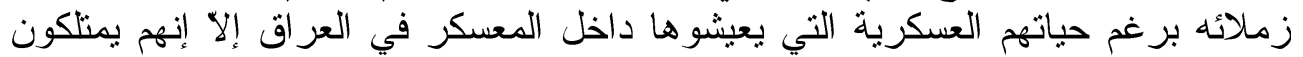

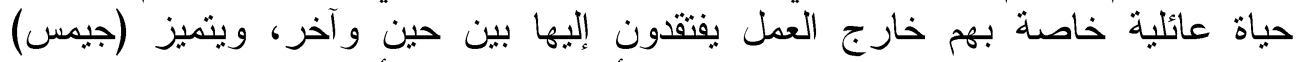

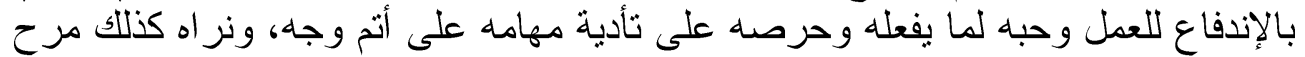

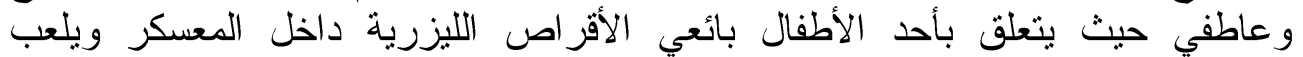

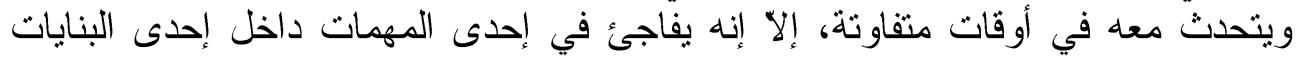

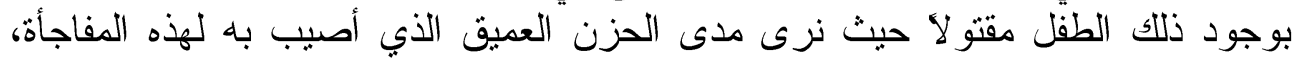

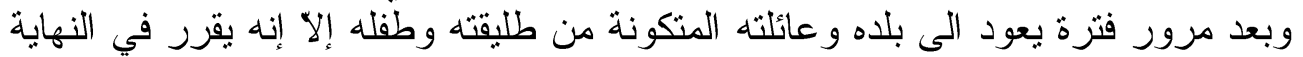

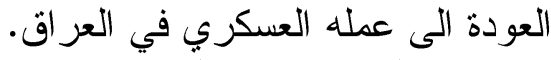

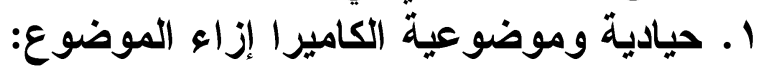

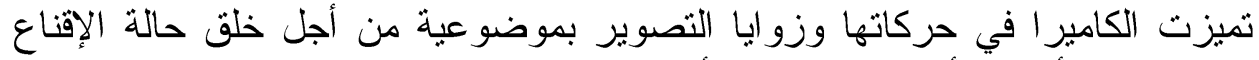

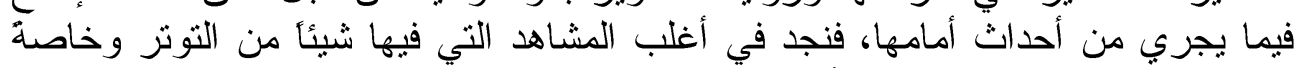

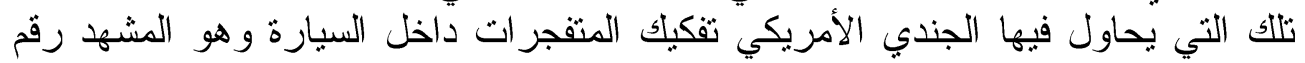

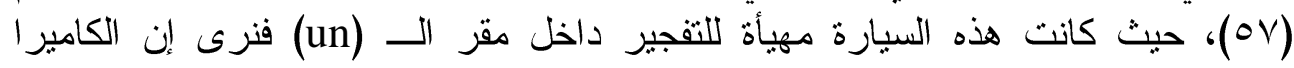


حاولت أن تتخذ موقع محايد إزاء حركة الجندي وعملية إثتغاله في تفكيك تلك الكي

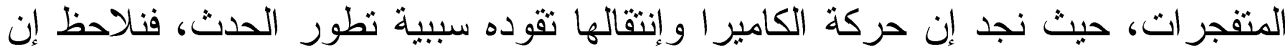

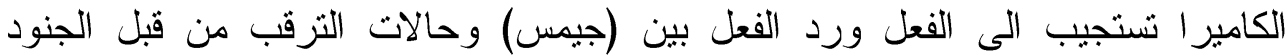

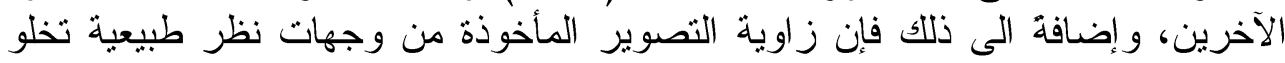

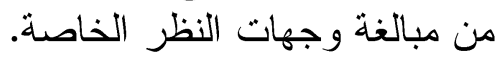

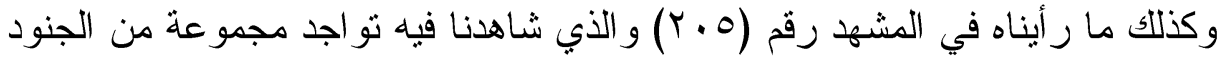

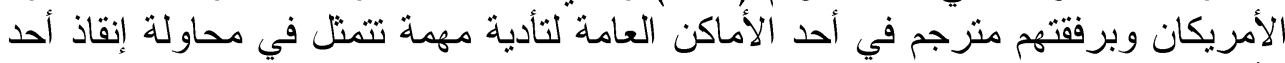

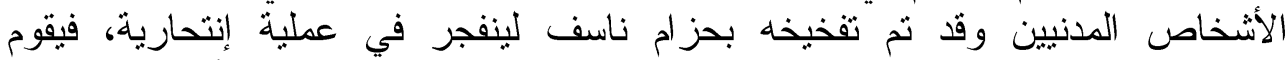

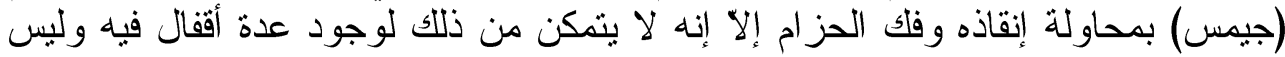

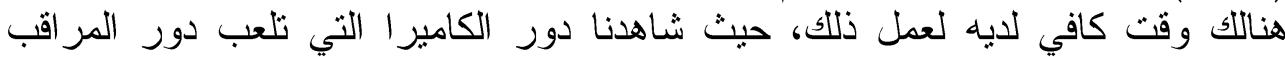

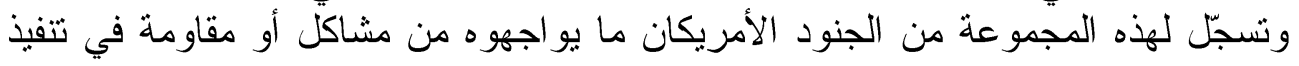
و واجباتهم.

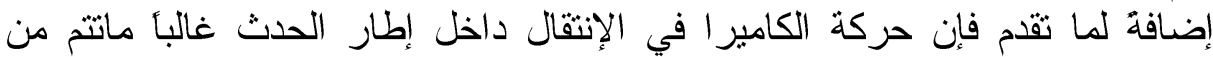

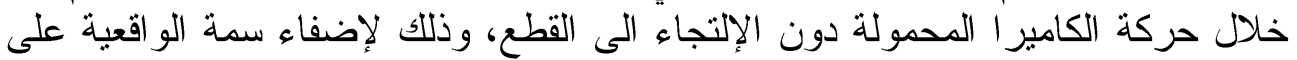
طبيعة ما يجري، فقد بدت حركة الكاميرا والإنتقال عشوائية بين الجنود و العجلات

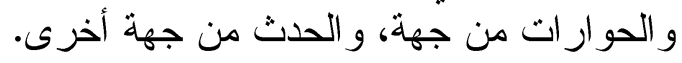

r. الميل نحو المراقبة والمتابعة والإتثاء في تسجيل الأحداث من قبل الكاميرا:

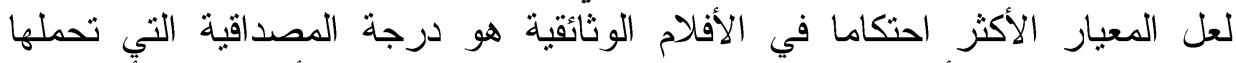

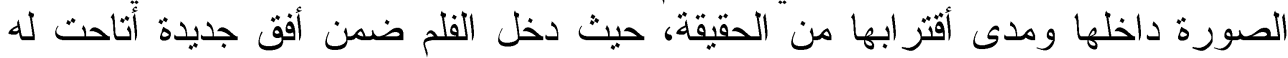
الحرية في أختبار النوع و الإسلوب لتقديم متته السردي، وبما إن الفلم الوثائقي غالباً ما التا

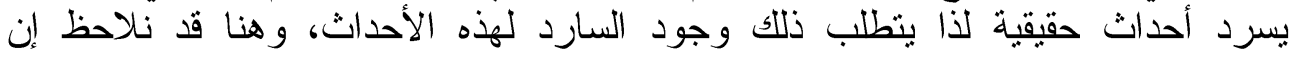

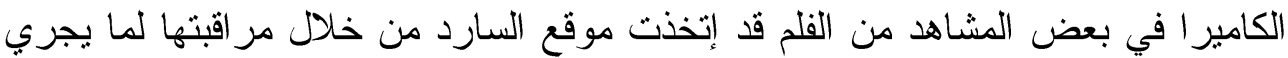

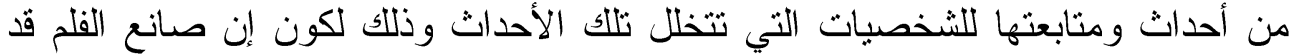

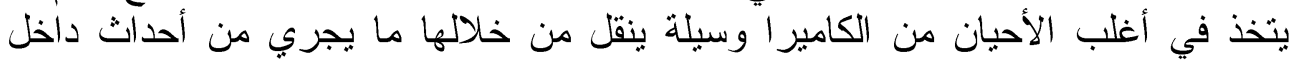

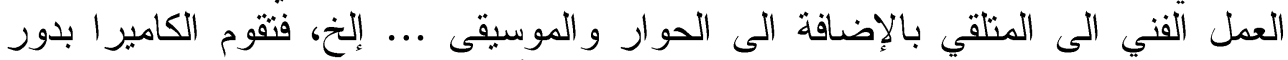

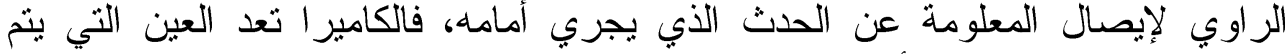

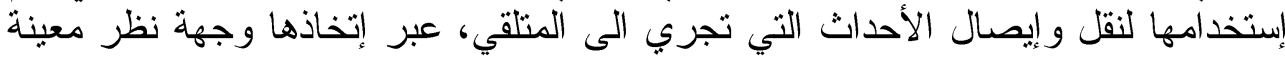

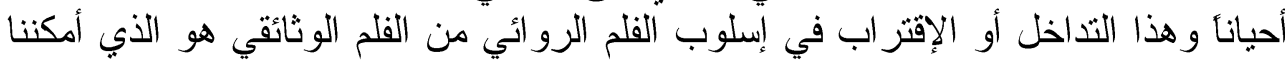
أن نلاحظه من خلال المشاهد التالية.

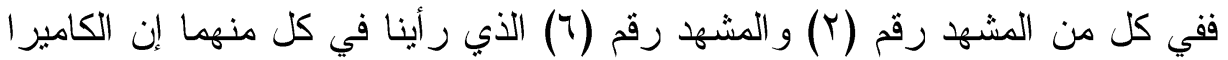

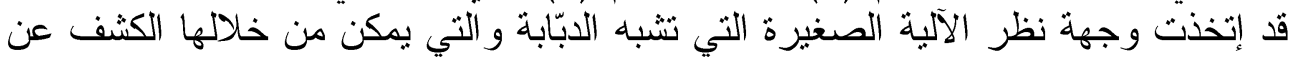

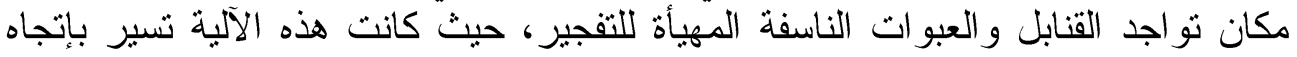

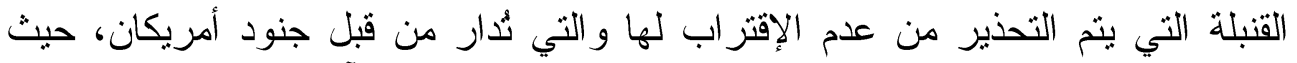

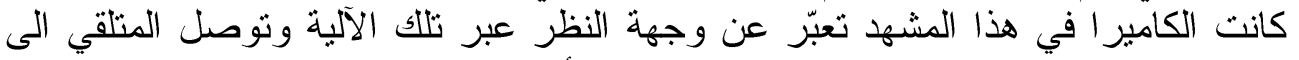

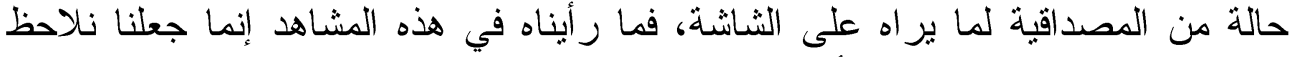

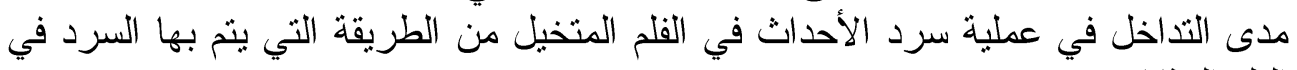

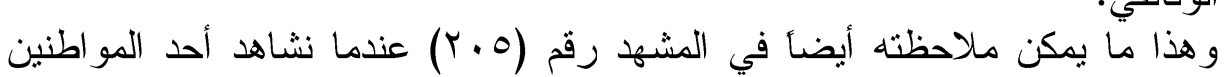

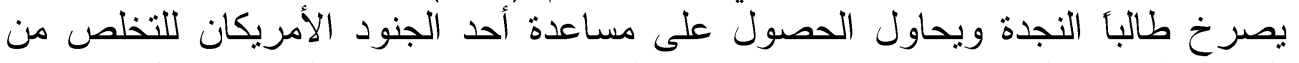
الحزام الناسف الذي يرتديه، حيث تم إنتاء الكامير ا في بداية هذا المشهد بشكل تتخذ فيه 


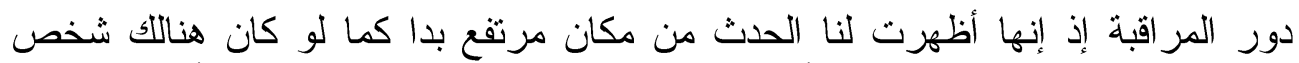

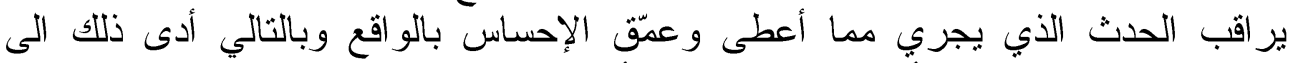

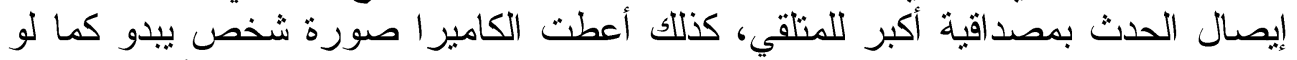

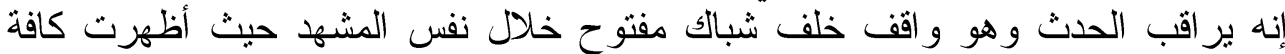

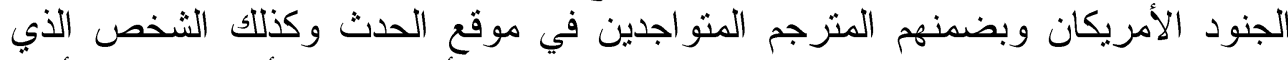

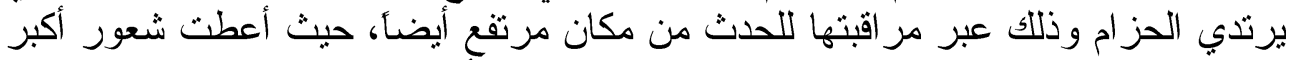

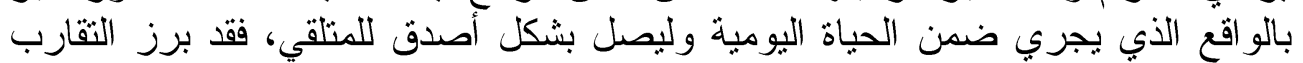

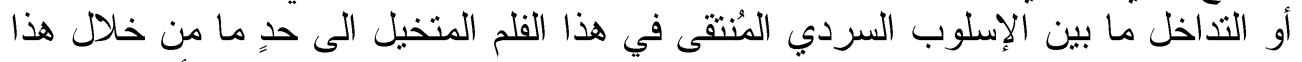
المشهد الى الإسلوب الذي يوّظف في الفلم الوثائقي والذي فلي عبره يتم سرد الأحداث داثل داخل

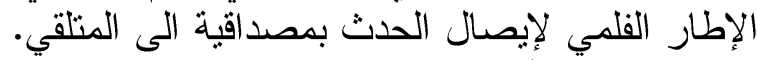

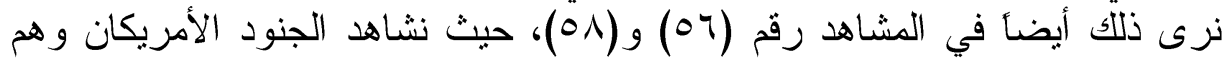

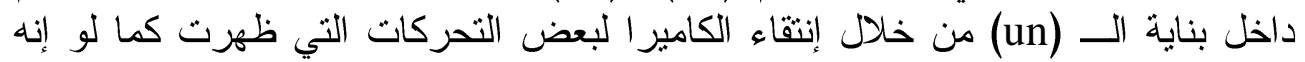

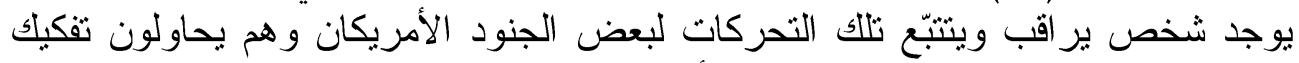

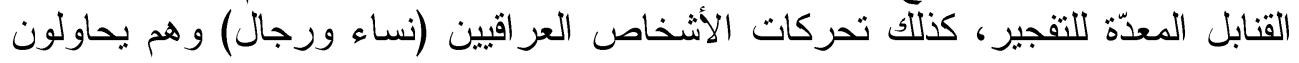

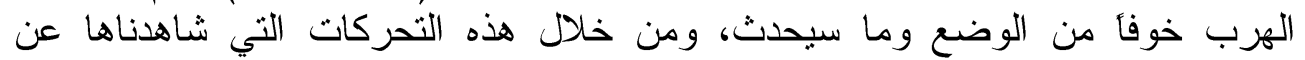

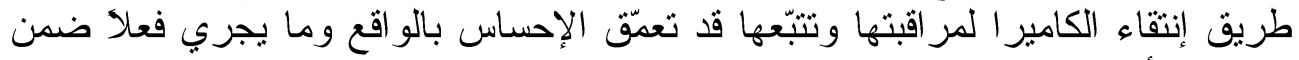

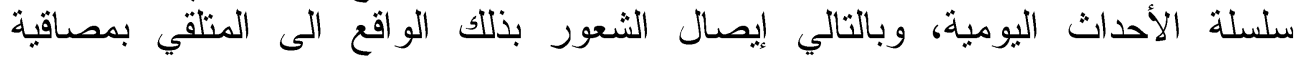

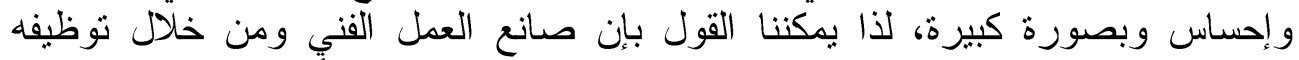

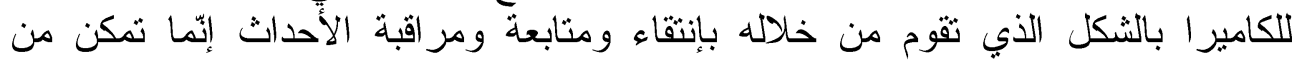

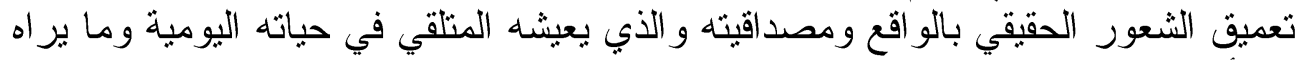

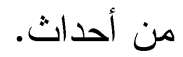

\section{r. عدم الإكتراث للتشويهات الفنية المتمثثة في:

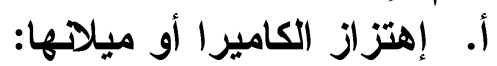

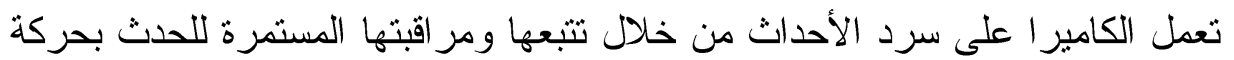

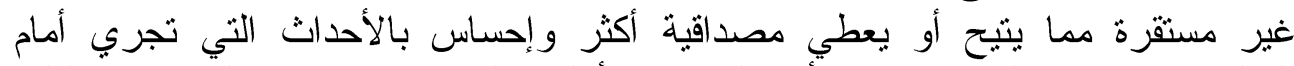

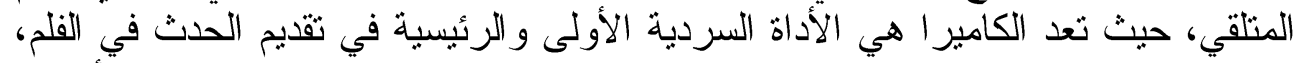

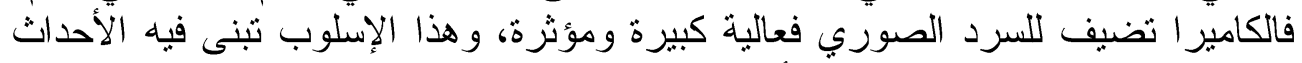

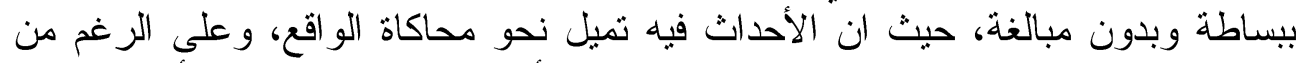

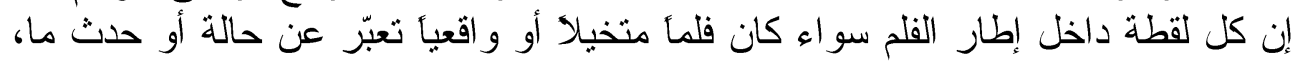

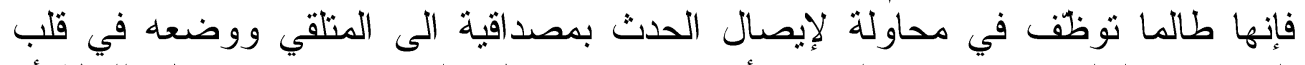

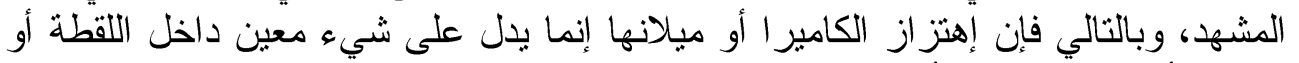

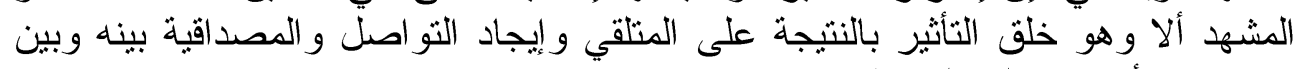
ماير اه من أحداث على الثاشّة.

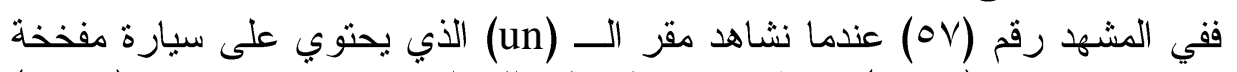

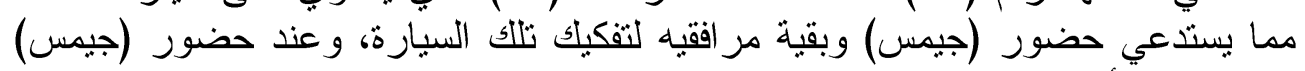

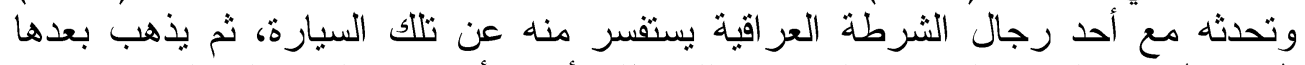

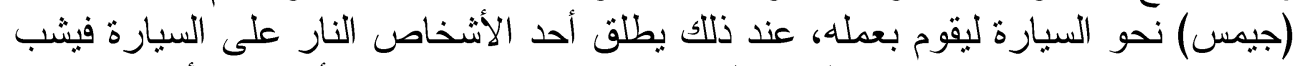

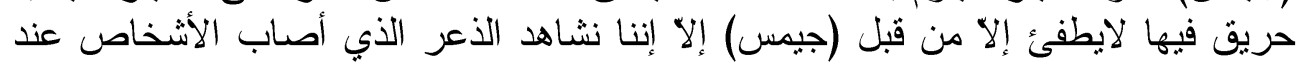


نشوب الحريق وقيام الجنود الأمريكان بإطلاق الرصاص على ذلك الثخص التهن التسبب فيه،

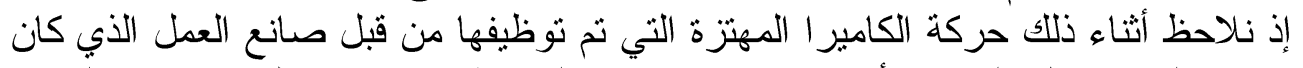

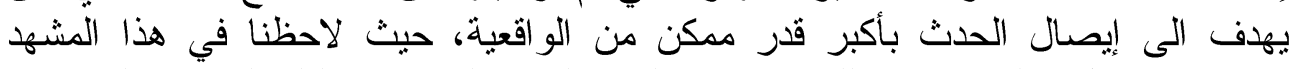

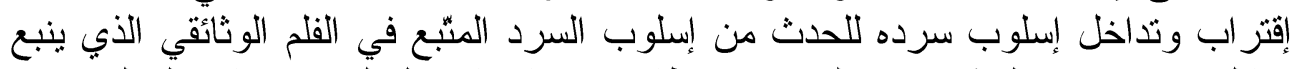

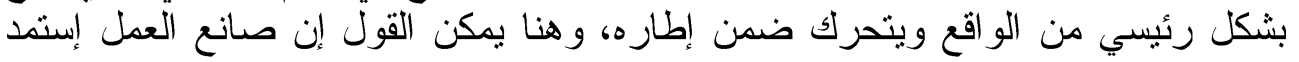

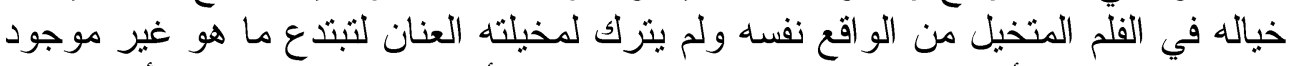

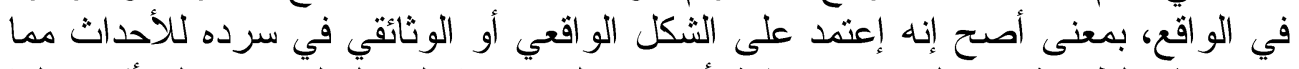

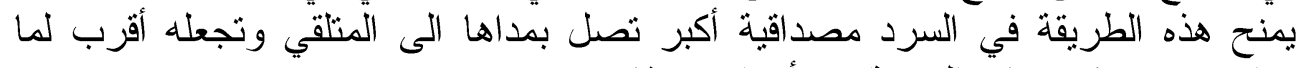
براه ويسمعه في حياته اليومية من أحداث لئن ووقائع.

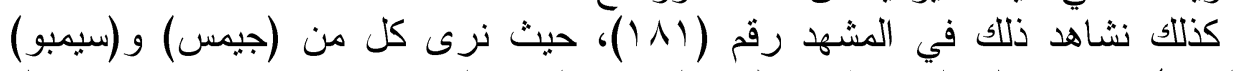

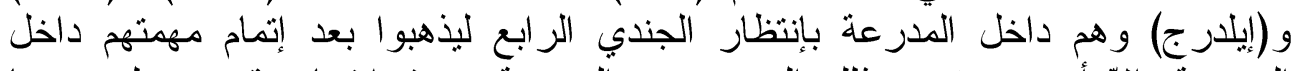

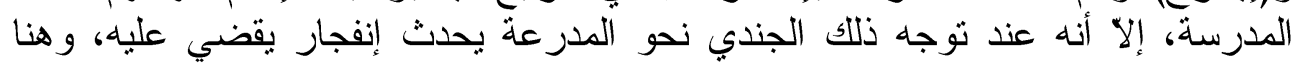

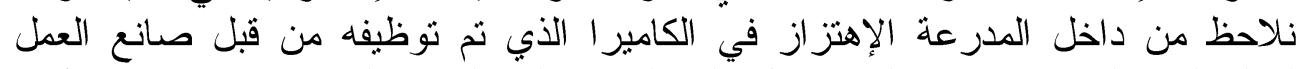

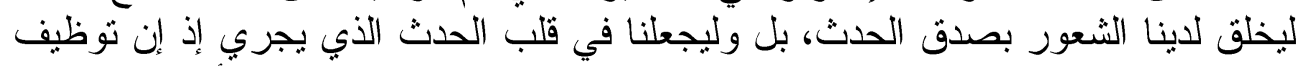

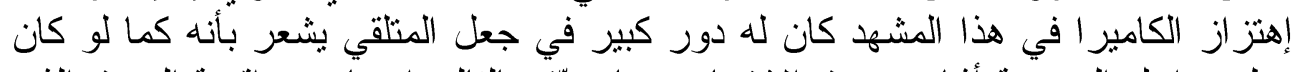

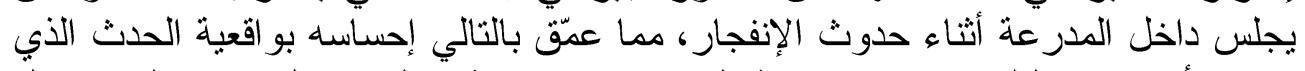

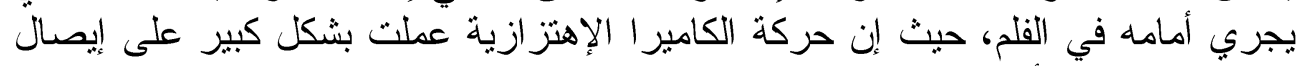

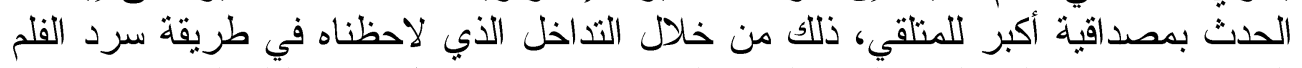

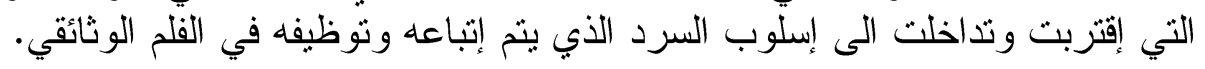

\section{ب. عدم الإهتمام بالبناء التثكيلي والتكودئ التكويني:}

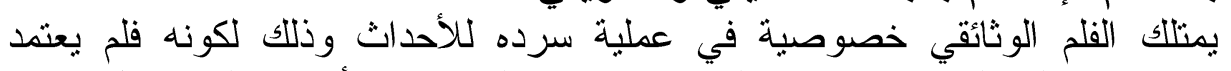

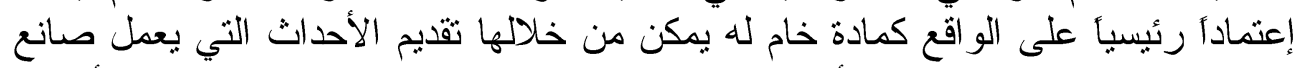

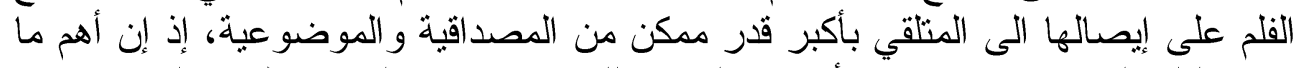

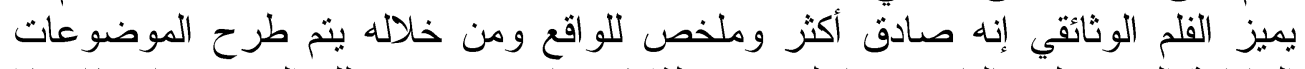

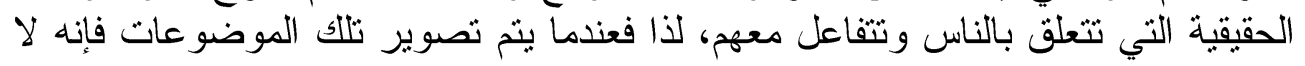

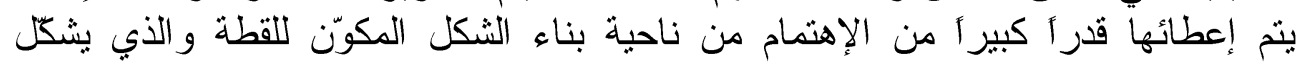

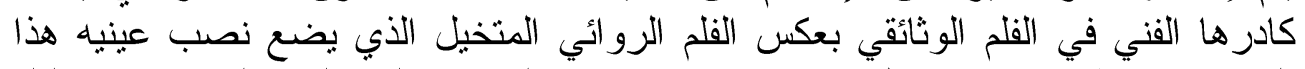

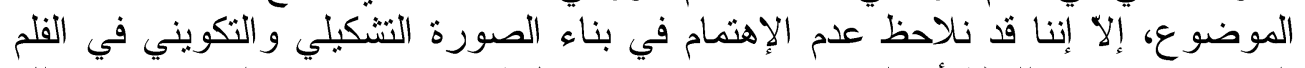

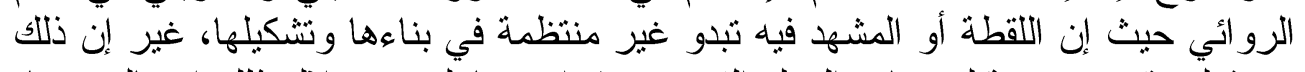

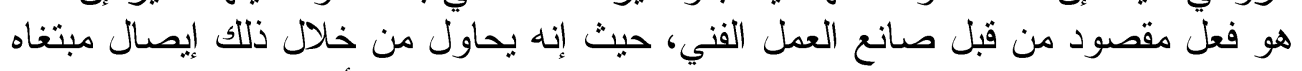

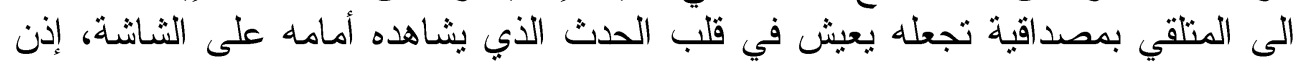

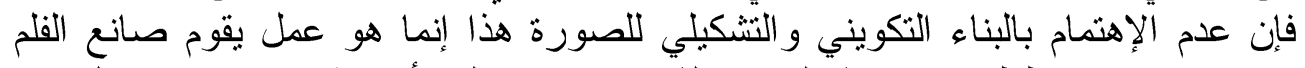

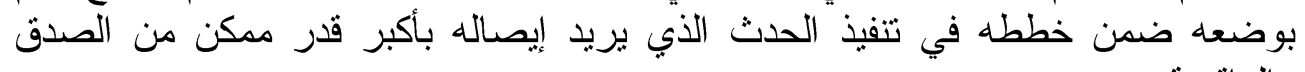

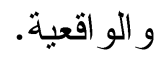

و هذا ما نشاهده في المشهد رقم (1) عندما نشاهد الجنديان الأمريكيان وهما يتحكمان

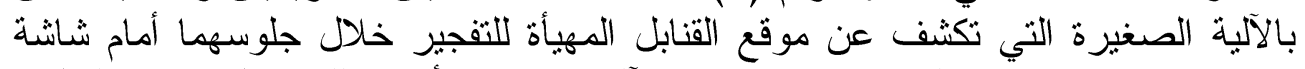

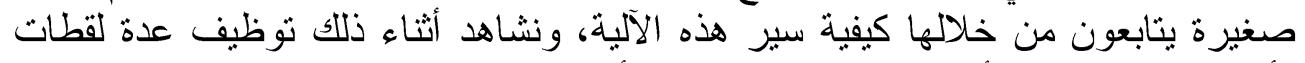

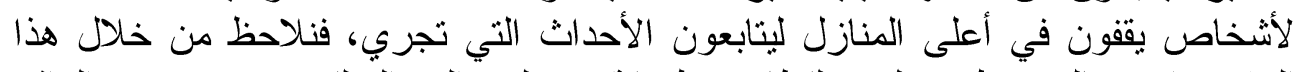

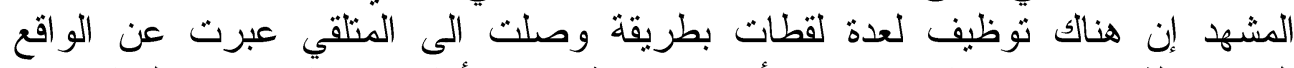

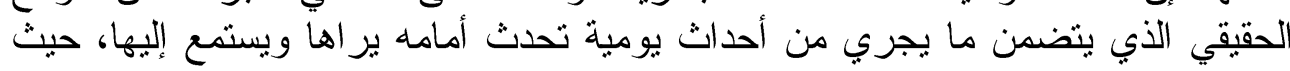


بدت هذه اللقطات ضمن المشهد كما لو إنها غير منتظمة في بناءها التشكيلي و التكويني

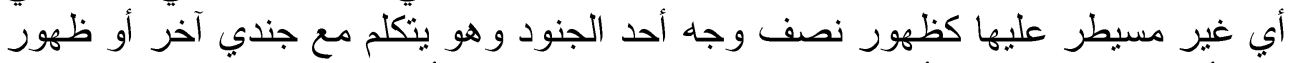

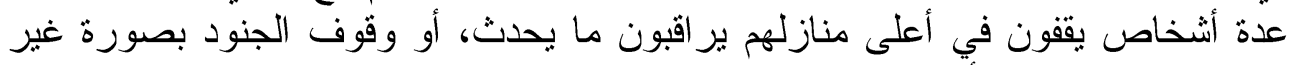

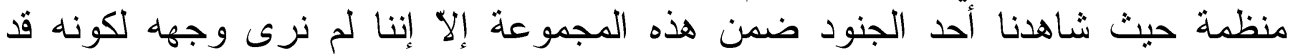

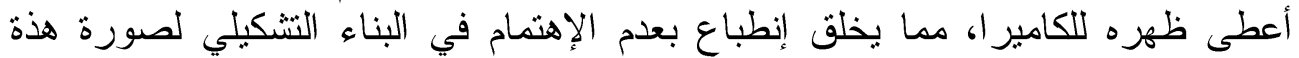

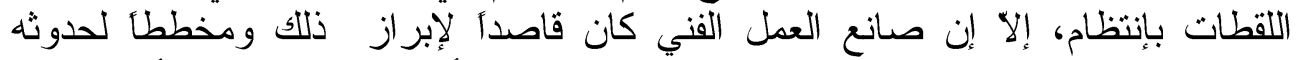

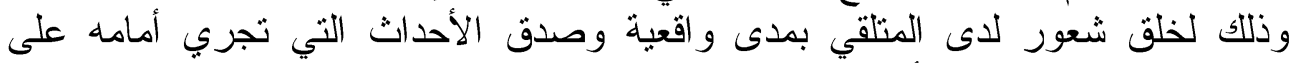
الشاشة وكما لو إن تلك الأحداث تجري وقت مشاهدتها مباشرةً

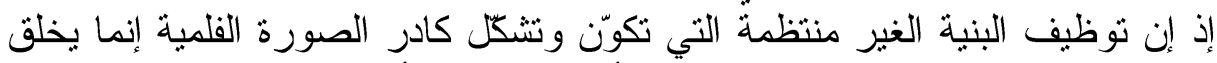

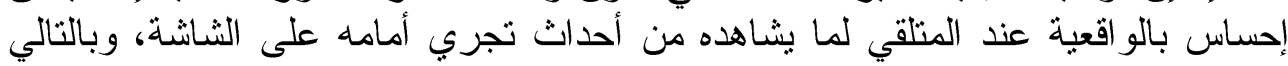

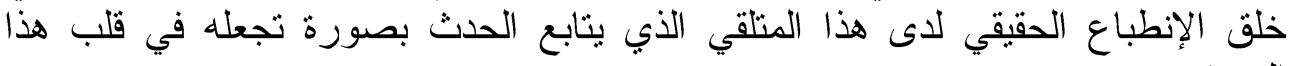

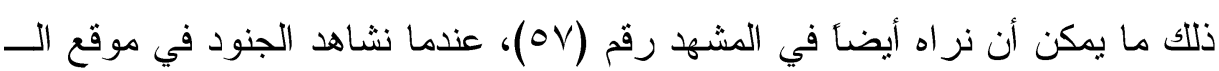

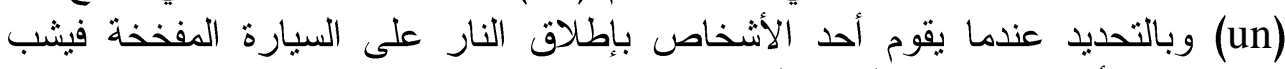

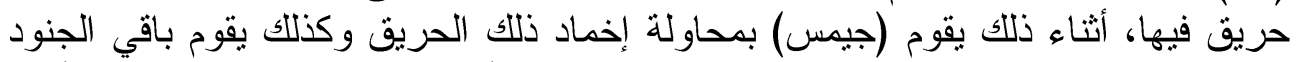

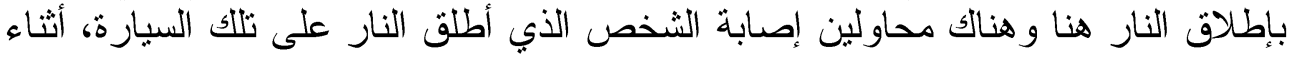

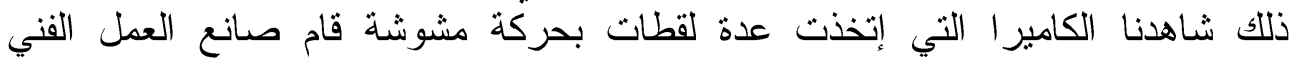

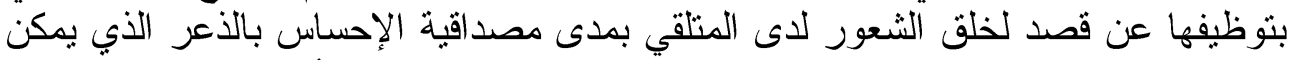

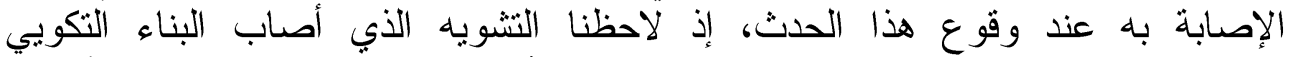

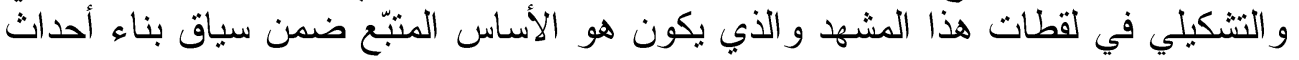

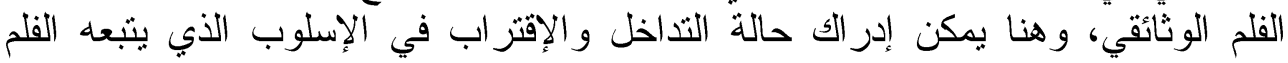

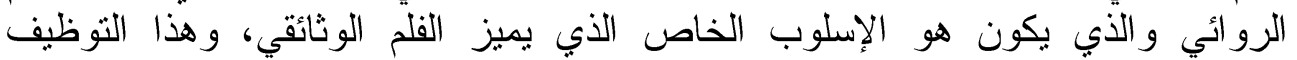

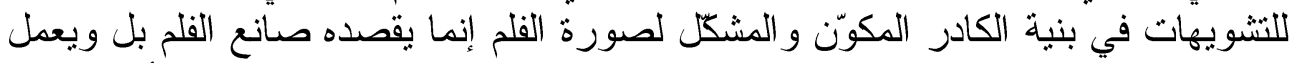

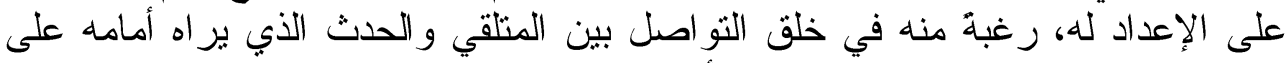

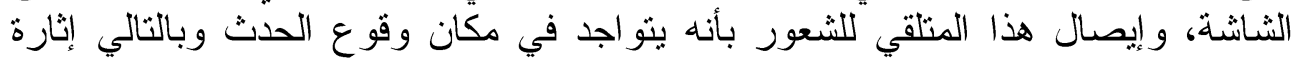

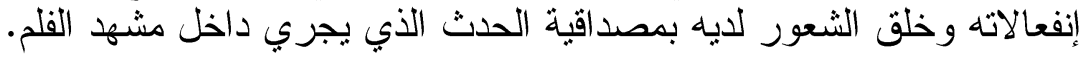

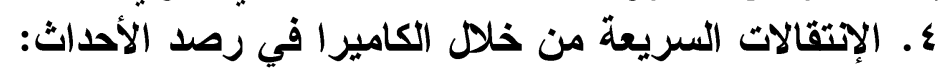

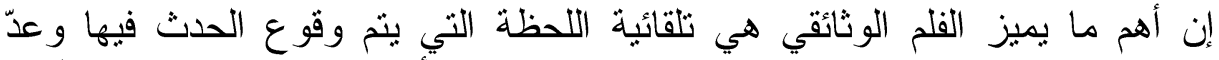

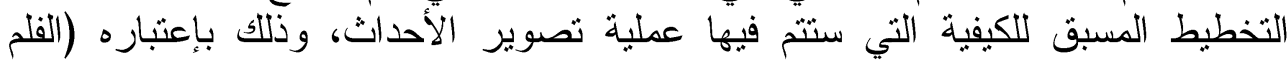

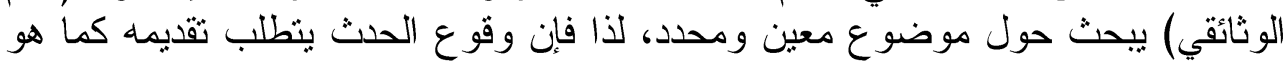

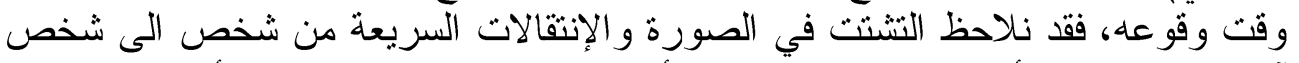

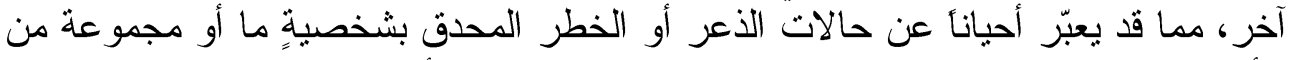

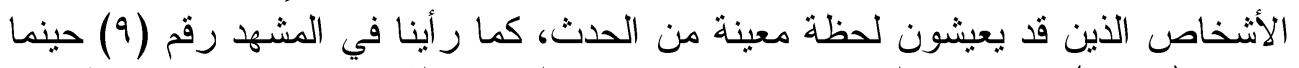

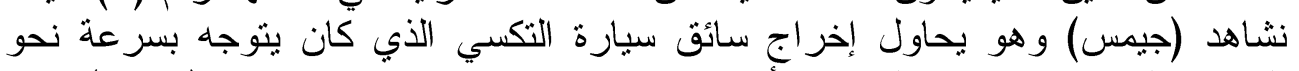

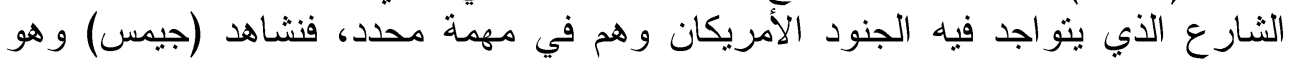

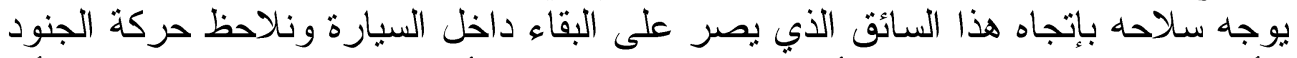

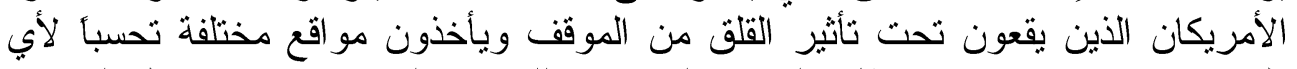
طارئ قد يحدث، فعند تحرّك الجنود المر اقبين للوضع الذي يجري نلاحظ التنقلات 
السريعة (swatch ban) بين الجنود التي وظفها صانع الفلم لإيصال مبتغاه الذي يتمثل

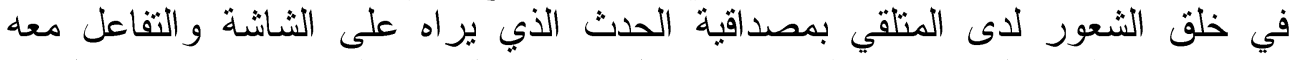

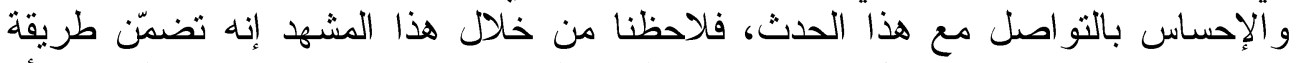

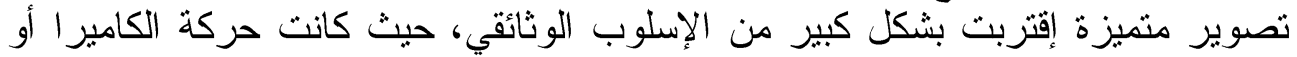

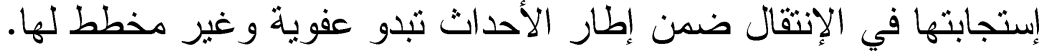

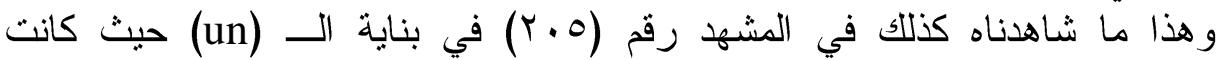

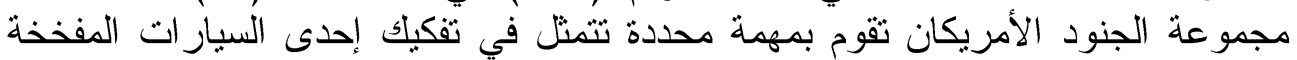

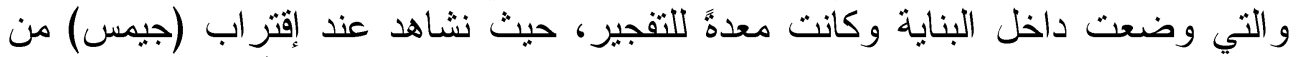

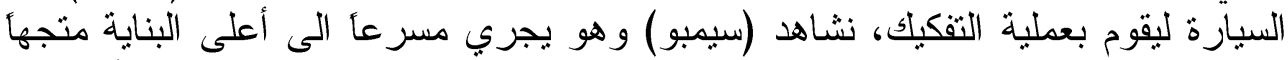

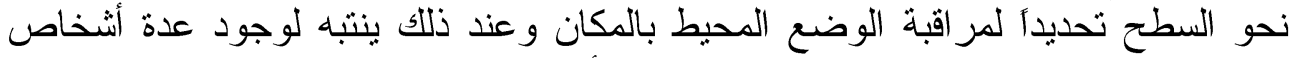

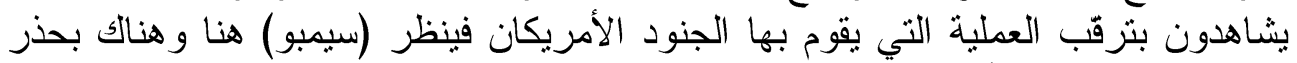

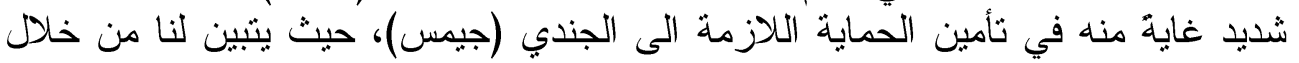

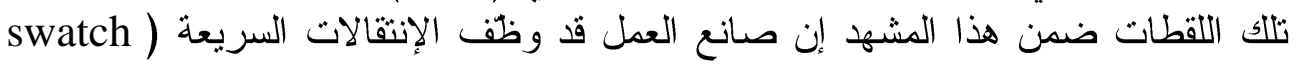

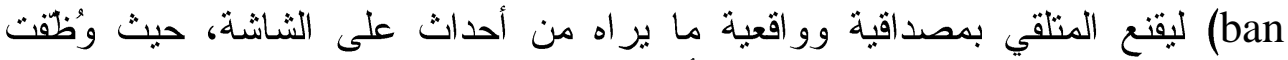

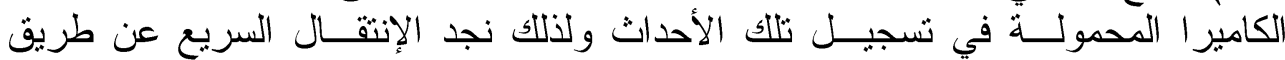

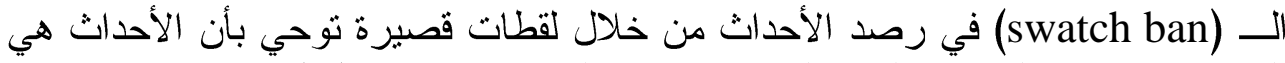

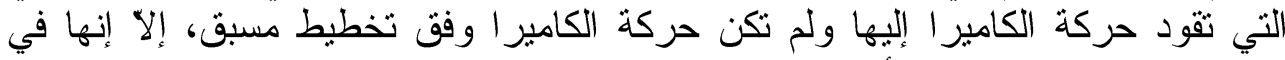

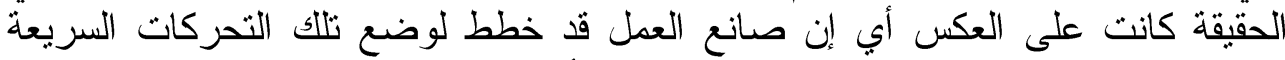

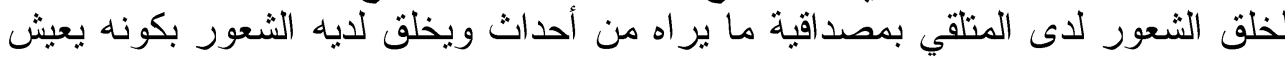
ضمن تلألك الاحداث. ه. عدم المبالغة في بنية الأحداث والأداء التمثيلي:

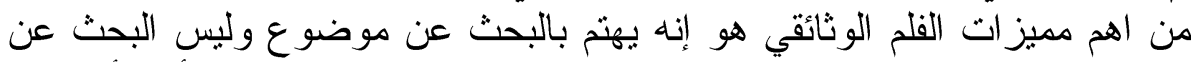

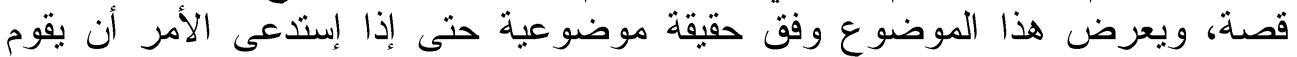

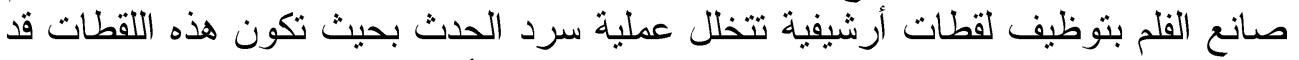

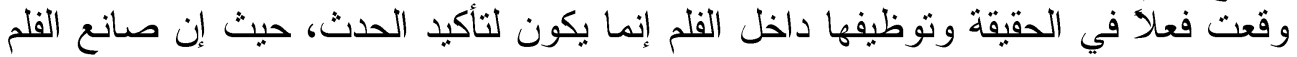

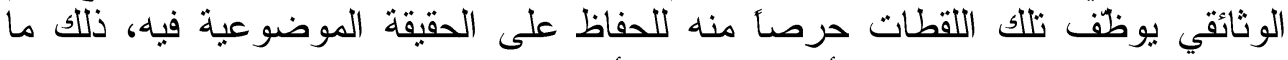

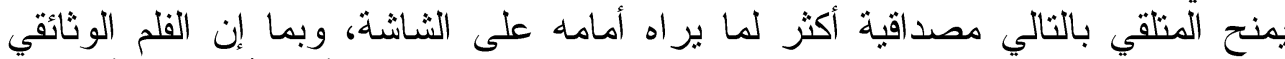

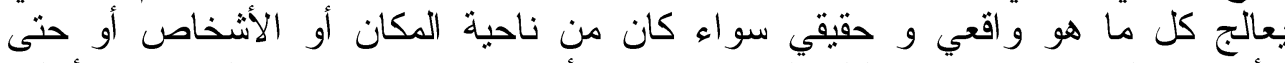

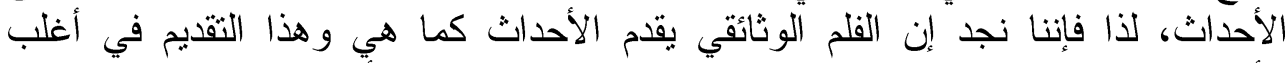

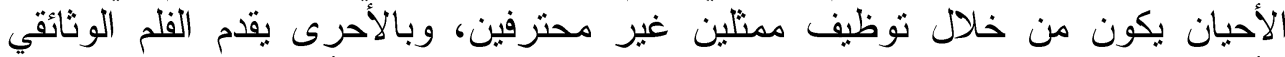

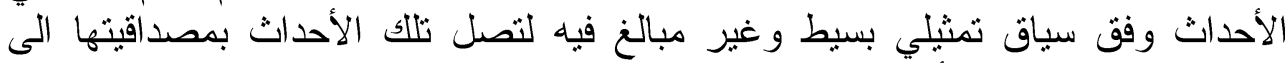

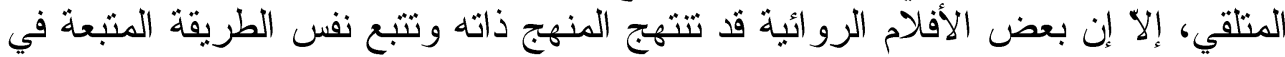

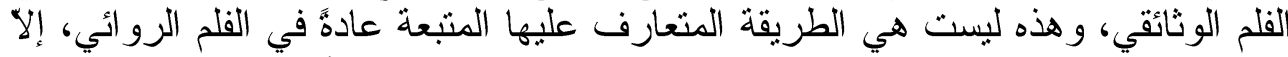

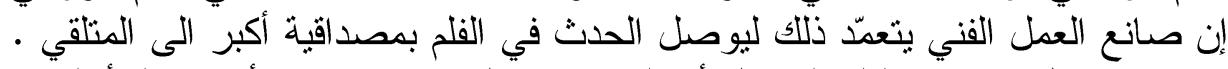

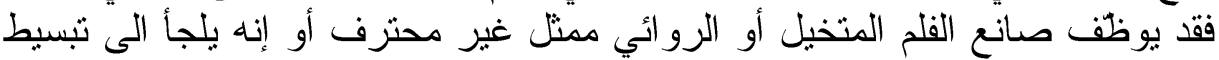

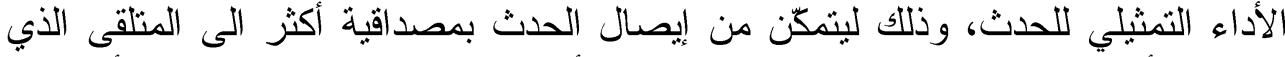

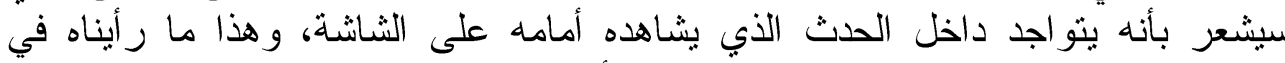

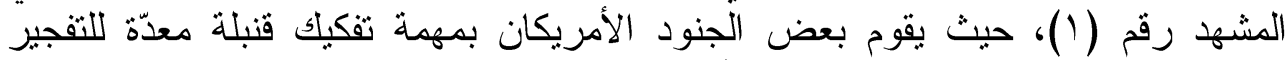
موضوعة في طريق عام يعج بالناس، أثناء ذلك نلاحظ هؤلاء الجنود وهم يطالبون الناس 
بالإبتعاد عن هذا المكان لوجود خطر قد يحلّ بهم، إذ لاحظنا الكيفية التي تم تقديم هذا

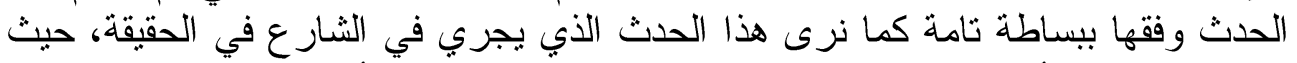

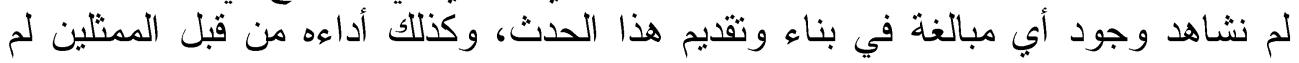

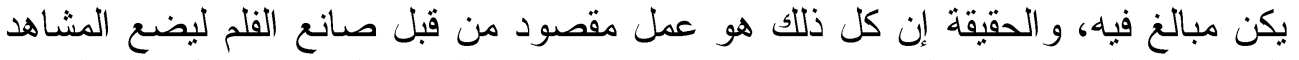

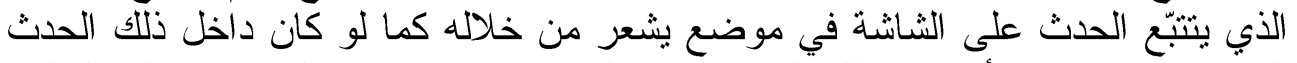

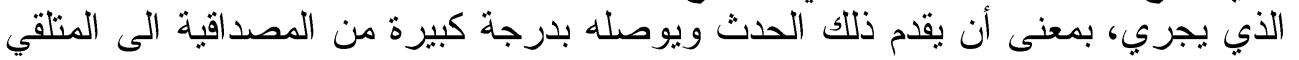

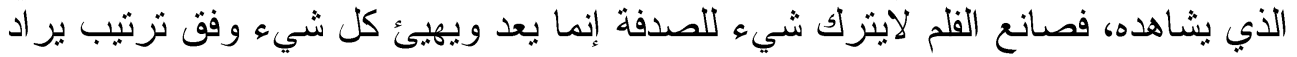

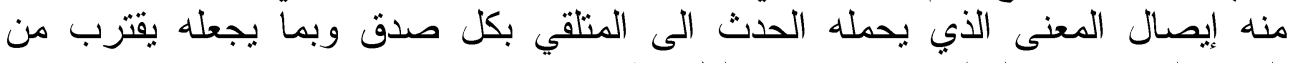
الو اقع الذي يعيشه المتلقي ضمن بيئته الطبيعية.

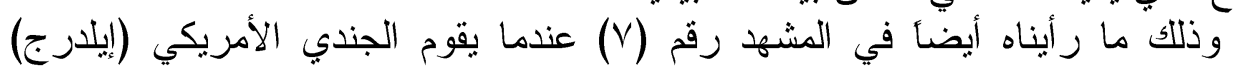

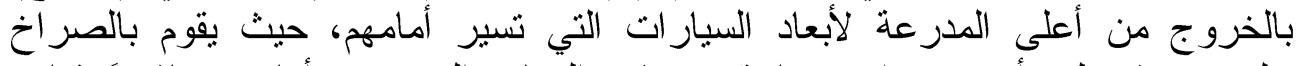

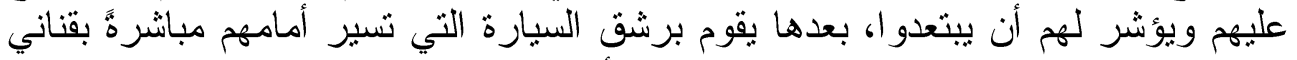

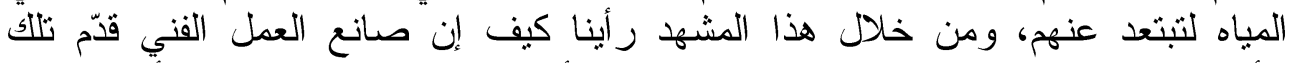

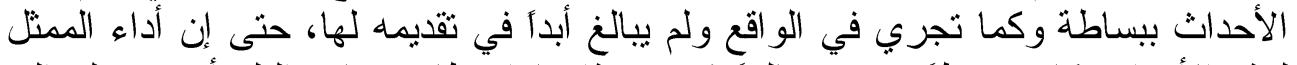

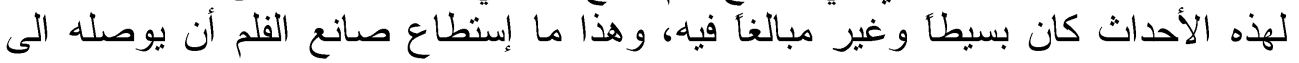

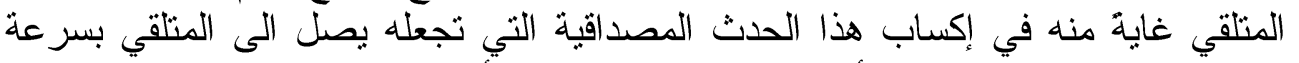

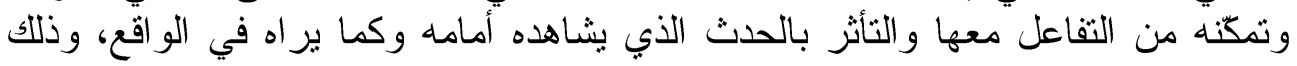

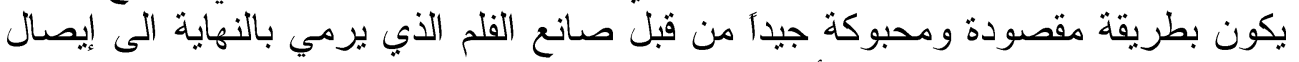

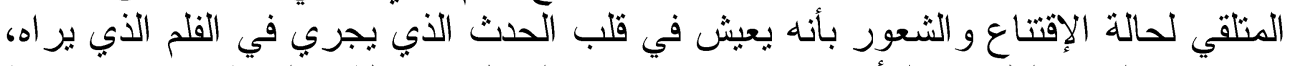

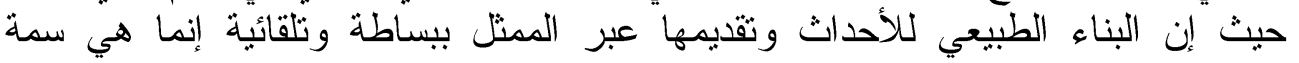

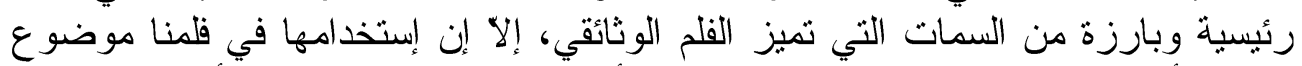

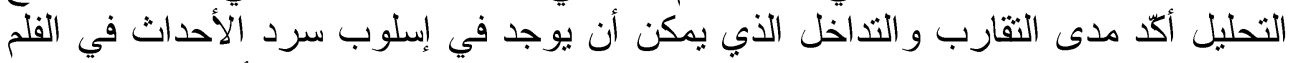

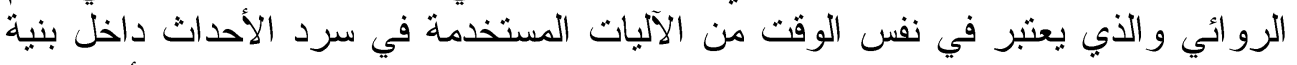

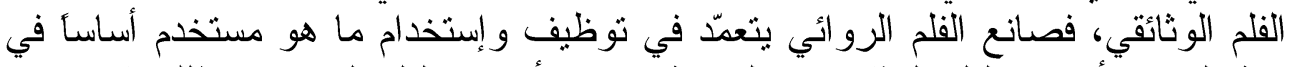

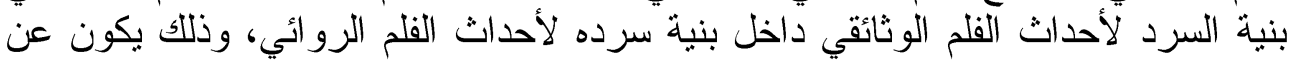

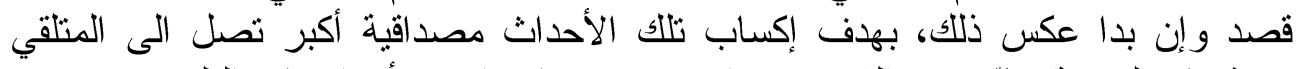

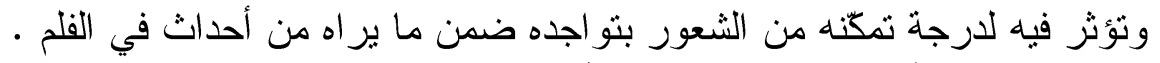

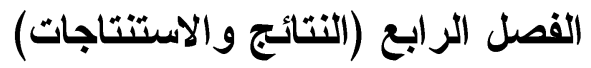

\section{الأنتائج:}

ا. إعتماد حيادية الكاميرا وموضوعيتها في سردها للحدث الواقعي داخل بنية الفلم المتخيّل.

r. إتخاذ الكاميرا موقع المر اقبة للحدث و المتابعة في ثوثيق سرد الأحداث داخل الفلم

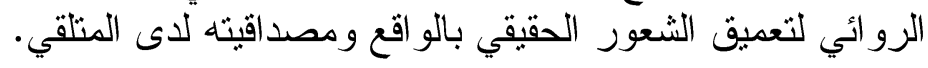

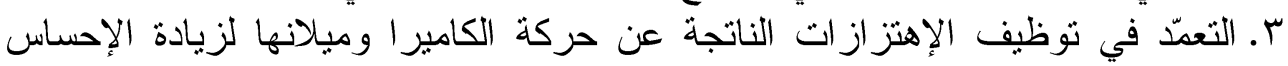

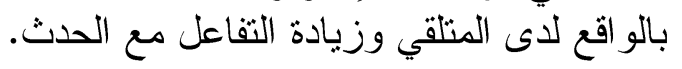

ع. توظيف الإنتقالات العشو ائية لإضافة سمة الو اقعية على طبيعة الأحداث التي التي تجري.

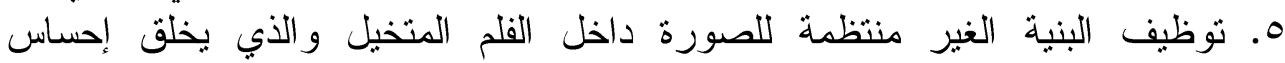
بالو اقعية عند المتلقي. 
7. البناء الطبيعي للأحداث وتقديمها بشكل عفوي وتلقائي داخل بنية الفلم المتخيّل

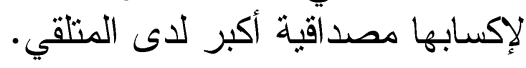

الاستنتاجات :

ا • بعتبر السرد السينمائي عنصر مهر جدأ في البنى التركيبية للفنون.

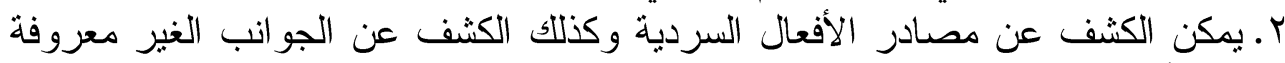

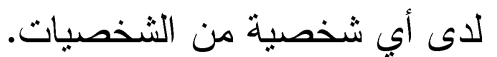
r. تعبّر الأنساق السردية عن الكيفية الخاصة في سرد الفئة الأحداث.

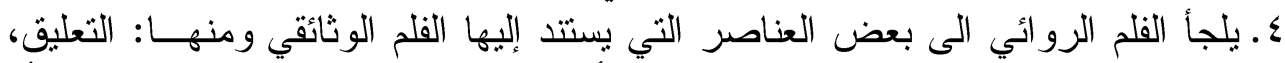

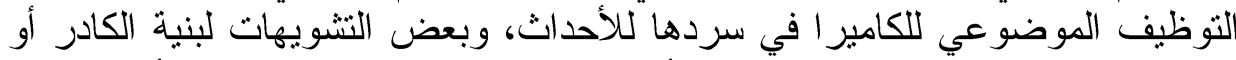

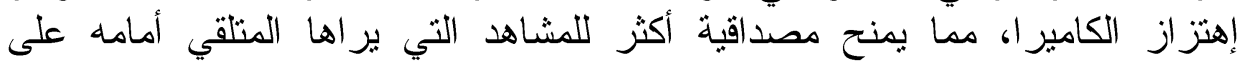
الشاشة.

0. يتميز السرد في الفلم الوثائقي بالبساطة و الموضو عية.

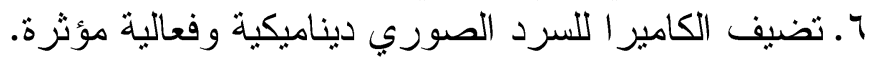




\section{Abstract \\ The film narrative overlaps between the imagined and the reality (Pain Closet film as a model) By Mo3taz Mohamed And Hider fasal}

A feature film is a film that relies on the many techniques, ranging between scientific and artistic pure, that many disciplines will enter and do a lot of linguistic elements for the production of an integrated cinematography, and among the artistical techniques used by the feature film is to find a kind of relationship between the reality of reality as a document and imaginary and as a kind of disciplined imagination, This relationship is what led the researcher to determine the subject of his research at the following address: The interplay of the narrative between the visual and the reality (The Hurt Locker "Model"). The researcher has divided this subject into four chapters that came as follows:

o Chapter I (the methodological framework): The problem of research included the following question:

What is the way in which documentary narratives are employed in the feature film?

And then the importance of research and research objectives as well as the limits of research.

o Chapter II (theoretical framework): It has been divided into three sections: The first search: (narrative concept and term)

The second research: dealing with narrative patterns in the feature film The third research: The privacy of the documentary narrative in the feature film.

o Chapter III (the research procedures) included:

Research Methodology: The researcher used the descriptive approach, and the research sample which was represented in the film ((The Hurt Locker) which was chosen as a descriptive sample to suit the subject of the research, the analysis unit, the analysis tool, and finally the analysis of the research sample.

o Chapter IV (Results and conclusions) included the results of the research reached by the researcher and most important:

1. To adopt camera neutrality and objectivity in the narrative of the real event within the structure of the imaginary film.

2. The camera has taken the observation site of the event and follow-up documenting events in the narrative film to deepen the real sense of reality and credibility of the recipient.

As well as the conclusions of the researcher in light of the results of the research 
(1) ميخائيل روم ، أحاديث حول الإخر اج السينمائي ، ترجمة : عدنان مدانات ، بيروت ، دار الفارابي ، - ror

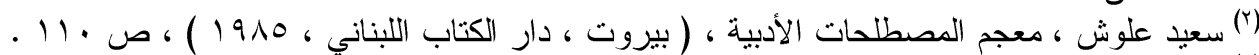

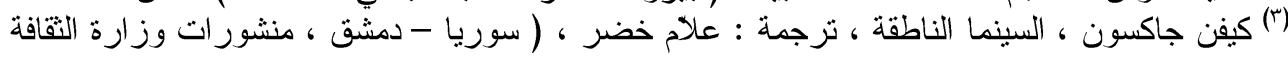

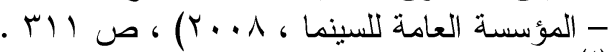

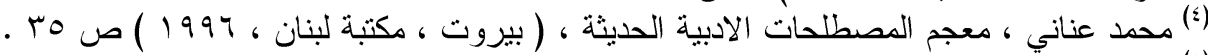

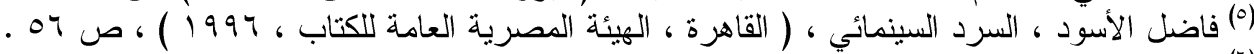

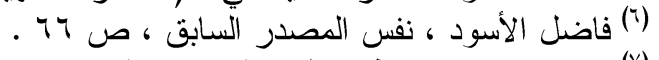

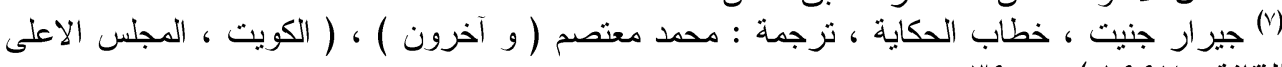

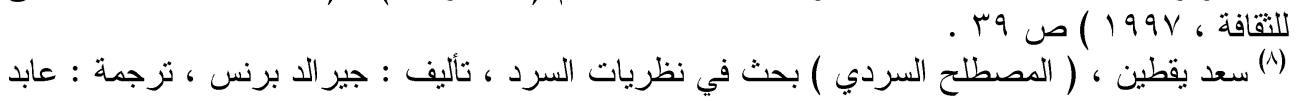

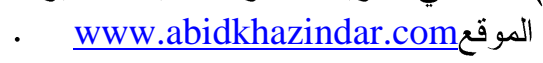

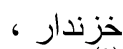

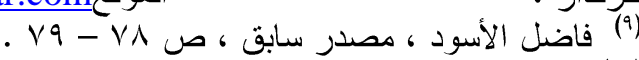

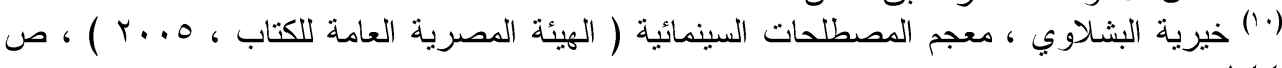
. $1 \leqslant \varepsilon$

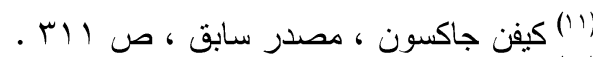
، أو آمنة يوسف جاكون ، تقنيات السرد في النظرية و التطبيق ، ( سوريا - اللاذقية ، دار الحوار للنشر و التنوزيع

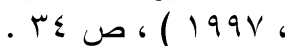

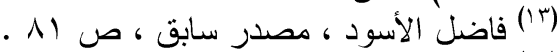

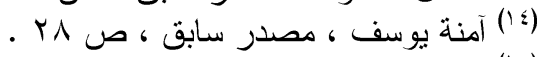

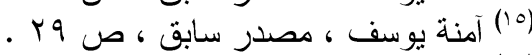

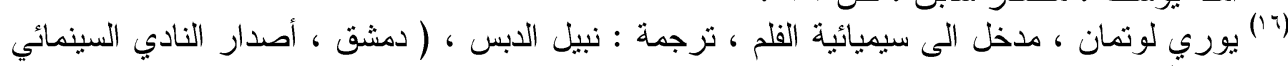
(1919. (ال)

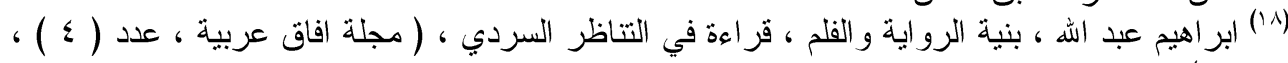

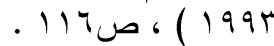

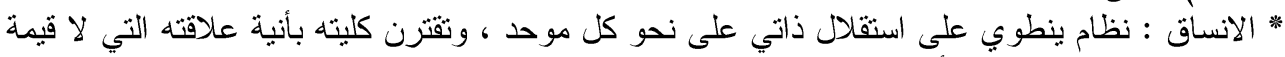

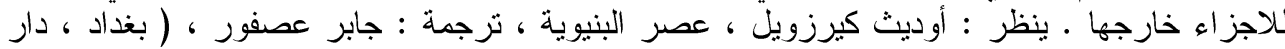

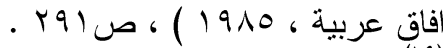

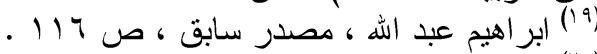

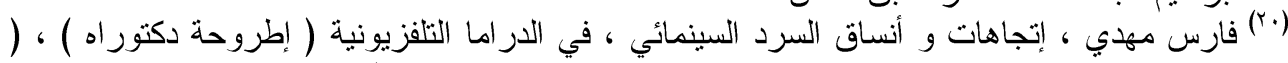

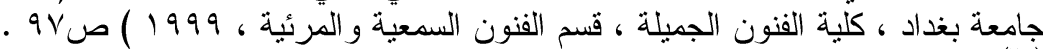

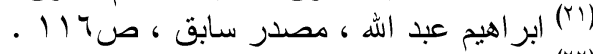

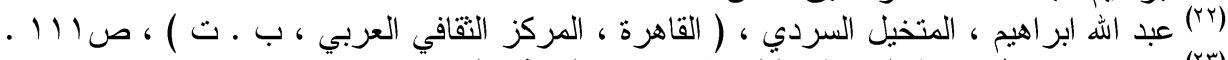

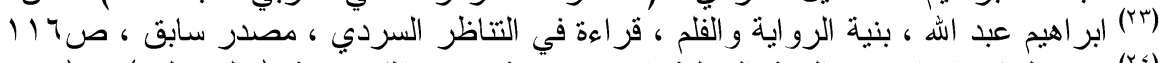

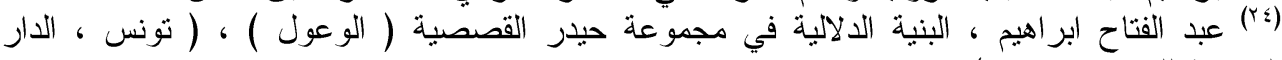

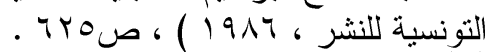

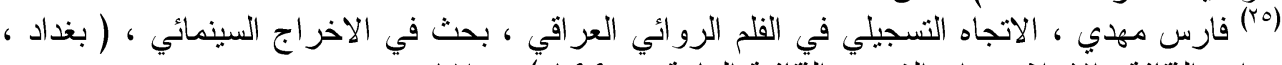

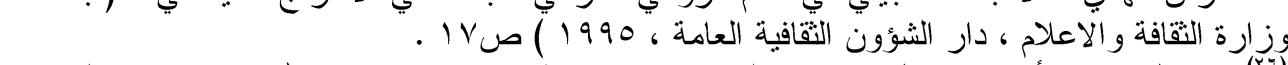

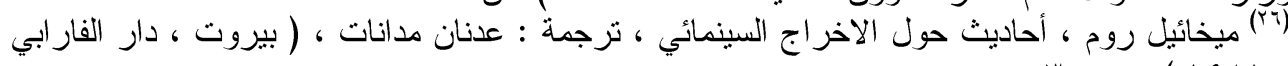

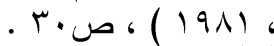
(rV)

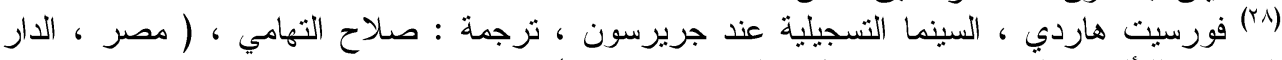

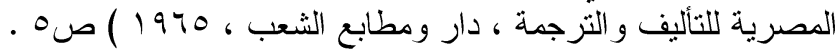




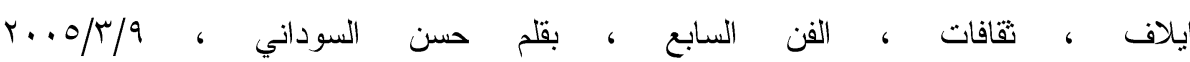

www.elaph.com.htm لمان" فارس مهدي ، الاتجاه التسجيلي في الفلم الروائي العراقي ، بحث في الاخراج السينمائي ، مصدر

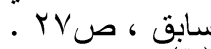

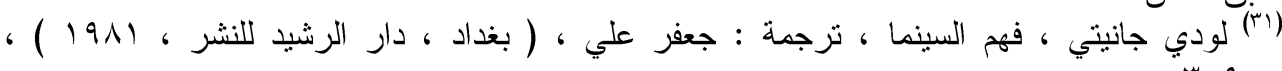
ص صو .

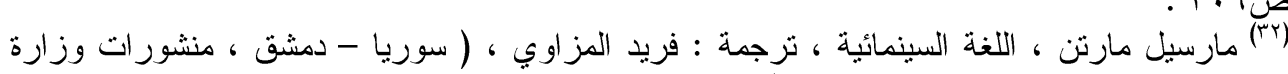

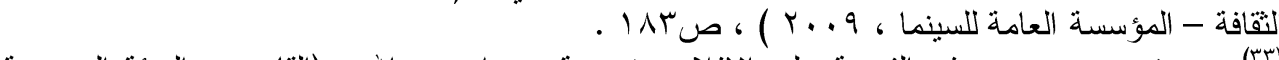

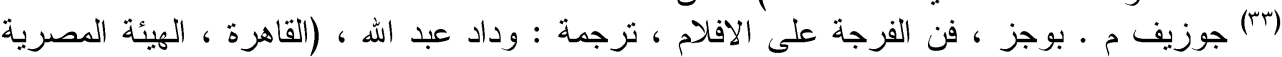

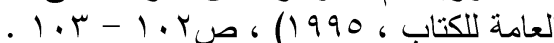

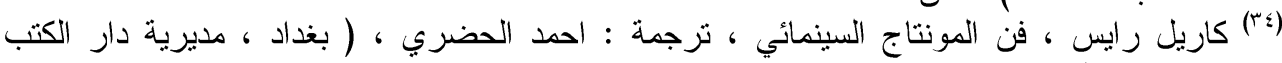

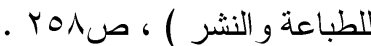

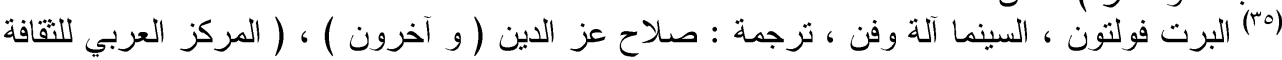

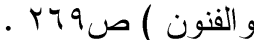

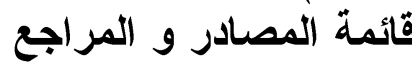
مصادر المعاجم و القو اميس:

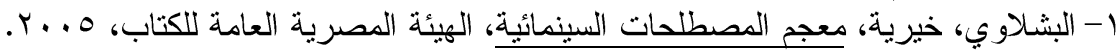

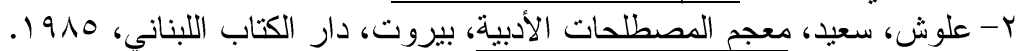

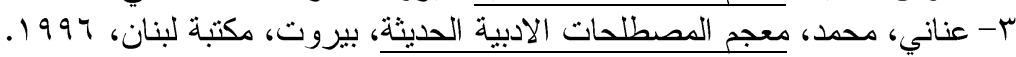

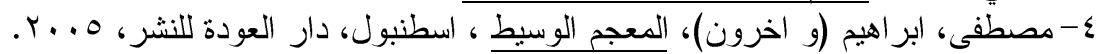

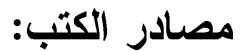

1- ابر اهيم، عبد الفتاح، البنية الدلالية في مجموعة حيدر القصصية (الوعول)، تونس، الدار التونسية

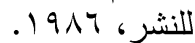

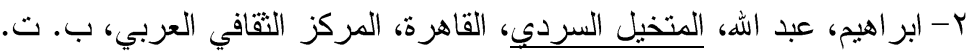

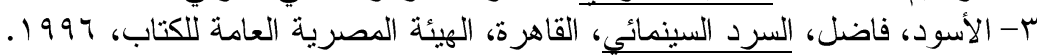

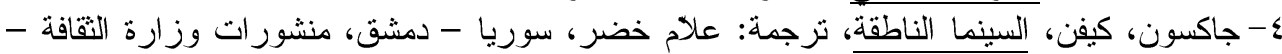

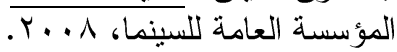

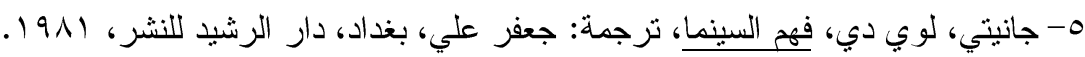

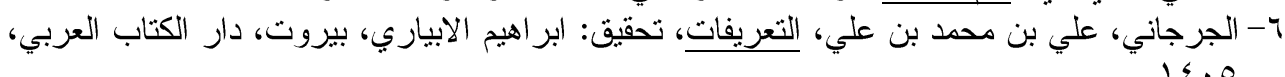
V- جنيت، جيرار، خطاب الحكاية، نرجمة: محمد معتصم (و آخرون)، الكويت، المجلس الاعلى للافقة، $.199 \mathrm{~V}$

^-ر رايس، كاريل، فن المونتاج السينمائي، ترجمة: احمد الحضري، بغداد، مديرية دار الكتب للطباعة

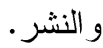

9-روم، ميخائيل، أحاديث حول الاخراج السينمائي، ترجمة: عدنان مدانات، بيزوت، دار الفارابي، • ا- فولتون، البرت، السينما آلة وفن، نزجمة: صلاح عز الدين (وآخرون)، المركز العربي للتقافة

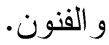

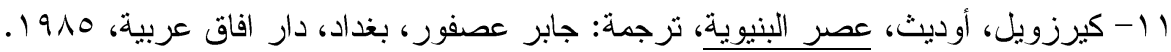

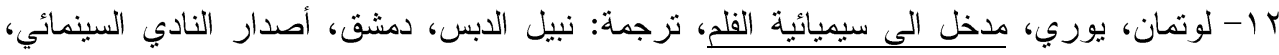


با - م.بوجز، جوزيف، فن الفرجة على الافلام، ترجمة: وداد عبد الله، القاهرة، الهيئة المصرية العامة

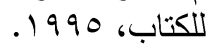

ع ا- مارتن، مارسيل، اللغة السينمائية، ترجمة: فريد المزاوي، سوريا-دمشق، منشورات وزارة الثقافة -

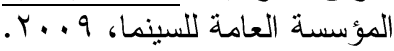

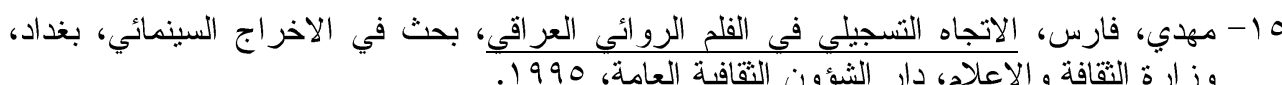

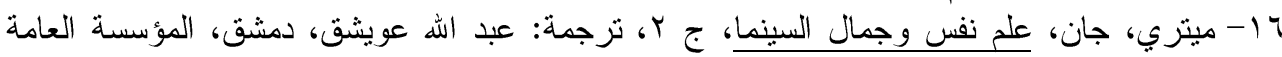

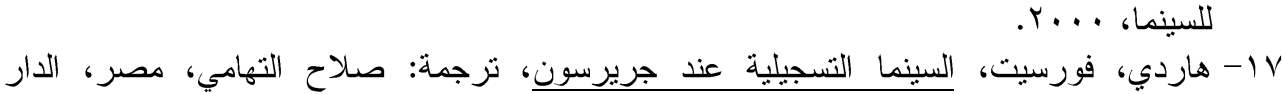

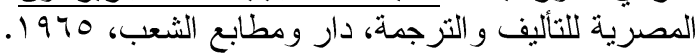

11 - يحيى، عادل، الو اقع و الدراما في السينما و التلفزيون، القاهرة، الهيئة المصرية العامة للكتاب، .r. . I

9 ا - يوسف، آمنة، تقنيات السرد في النظرية و التطبيق، سوريا-اللاذقية، دار الحوار للنشر و التوزيع، $.199 \mathrm{~V}$

\section{مصادر الرسائل و الاطاريح:}

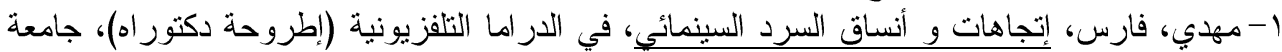

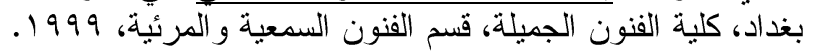

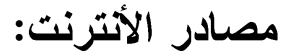

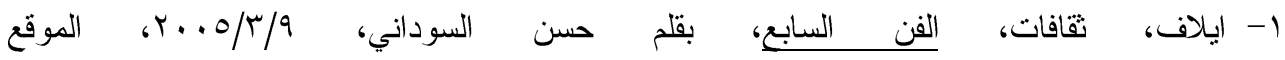

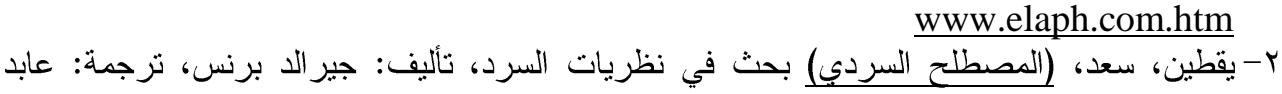

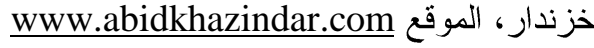

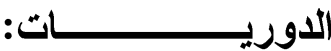
1--عبد الله، ابر اهيم، بنية الرواية والفلم، قراعة في التتاظر السردي، مجلة افاق عربية، عدد (ع)، 